\title{
BREVE ANÁLISE \\ DO REGIME JURÍDICO DO COOPERADOR
}

Maria Helena Salazar da Costa Lima

\section{INTRODUÇÃO}

Do amplo e interessante tema que constitui a matéria das cooperativas apenas iremos tratar do estatuto jurídico do sócio.

O estudo do tema será realizado tendo por base dois ordenamentos jurídicos e duas figuras distintas. Como se sabe, na ordem jurídica portuguesa, a figura da cooperativa não é tratada como uma sociedade comercial, ao invés do que acontece na lei espanhola sobre cooperativas, e em especial aquela sobre que incidiremos o nosso estudo, a lei sobre cooperativas da Galiza.

Apesar do Código Cooperativo ordenar a aplicação subsidiária do Código das Sociedades Comerciais, a cooperativa não tem o carácter de verdadeira sociedade.

Por esse facto, e dado que esta análise será realizada tendo por base o direito Português, em especial o Código Cooperativo, muito embora numa perspectiva comparativa com o regime das cooperativas na Galiza, sentimos necessidade de alterar o nome do trabalho que nos foi atribuído de modo a que fique conforme com a ordem jurídica nacional.

Com efeito, em vez do regime jurídico do sócio, adoptaremos como título do presente trabalho "o regime jurídico dos cooperadores", por serem assim designados os membros das cooperativas em Portugal.

Dentro desta matéria do estatuto jurídico dos cooperadores, trataremos com detalhe os seguintes aspectos a aquisição da qualidade de cooperador, os direitos e as obrigações dos cooperadores, o regime disciplinar; e finalmente a perda da qualidade de cooperador.

O método a adoptar será o da análise do Código Cooperativo Português, aprovado pela Lei 51/96 de 7 de Setembro, fazendo o estudo 
comparado com a Lei de Cooperativas da Galiza, a Lei 5/1998 de 18 de Dezembro.

A elaboração deste trabalho tem por base a apresentação oral do mesmo, cuja duração foi fixada em 15 minutos, pelo que apenas nos centraremos nas questões mais relevantes do estatuto jurídico dos cooperadores nas cooperativas Portuguesas e dos sócios nas cooperativas da Galiza. Fica assim, de fora deste trabalho a análise doutrinal e jurisprudencial.

\section{Aquisição da qualidade de cooperador}

De acordo com o artigo $31 .^{\circ} \mathrm{n} .^{\circ} 1$ do Código Cooperativo Português' podem adquirir a qualidade de cooperadores de uma cooperativa de primeiro grau ${ }^{2}$ todas as pessoas que preencham os requisitos e condições previstos no Código Cooperativo, na legislação complementar aplicável aos diversos ramos do sector cooperativo ${ }^{3}$, nos estatutos da cooperativa, e requeiram à direcção que as admita.

Da análise da referida norma concluímos serem vários os requisitos de que depende a aquisição da qualidade de cooperador.

Em primeiro lugar tal estatuto só poderá ser atribuído a pessoas singulares ou colectivas.

No que respeita às pessoas singutares constata-se que o Código Cooperativo nada refere quanto à capacidade jurídica para adquirir a qualidade de cooperador, pelo que se aplicam, nesta matéria, as normas gerais, constantes dos artigos $122 .^{\circ}$ e seguintes do Código Civil. ${ }^{\wedge}$

Da aplicação dessas regras resulta que a capacidade jurídica plena apenas se adquire com a maioridade, que como já referimos se

\footnotetext{
'Com este artigo se inicia o caṕtulo IV do Código Cooperativo sob a designação de "cooperadores".

"O artigo 5." do Código Cooperativo Português distingue duas espécies de cooperativas: as de primeiro grau e as de grau superior. As de primeiro gran são aquelas cujos membros sejan pessoas singulares ou colectivas, enquanto as de grau superior são as uniōes, as federações, e confederações de cooperativas.

"De acordo com o artigo 4." do Código Cooperativo prevêem-se sem carácter de taxa-" tividade os seguintes ramos de cooperativas: consumo, comercialização, agrícola, crédito, habitação e construção, produção operária, artesanato, pescas, cultura, serviços, ensino e solidariedade social.

"De acordo com o artigo $122{ }^{\circ}$ Código Civil tem plena capacidade para o excrcício de direitos aqueles que tenham completado 18 anos de idade.
} 
situa hoje nos dezoito anos de idade. No entanto, da análise dos vários diplomas complementares aplicáveis aos diversos ramos de cooperativas, ${ }^{5}$ constatamos que se prevê a possibilidade de serem admitidos membros menores de idade, desde que tenham completado os 14 anos, sendo nesse caso, a incapacidade suprida através dos institutos do poder paternal e da tutela, conforme previsto no artigo $124 .^{\circ}$ do Código Civil. ${ }^{6}$

Além das pessoas singulares podem também ser admitidas as pessoas colectivas. ?

Acresce ainda que, só poderão ser sócios aqueles que preencherem os requisitos e condiçốes previstos no Código Cooperativo, na legislação específica para os diferentes ramos de cooperativas e ainda nos estatutos, e que o solicitem à direcção.

Sobre este aspecto trata o artigo $18{ }^{\circ} 1$. da Lei de Cooperativas da Galiza. Este artigo procede também como o Código Cooperativo Português à distinção entre cooperativas de primeiro e segundo grau, pelo que são diferentes, aqueles que podem ser sócios das cooperativas, consoante ela seja de primeiro ou segundo grau. No que concerne às cooperativas de primeiro grau, tal como no Código Cooperativo também na Lei de Cooperativas da Galiza não se impõe especiais requisitos quanto à capacidade, o que significa aplicarem-se também as normas gerais da Lei Civil.

No entanto, comparativamente com o Código Cooperativo Português podemos afirmar que este preceito se apresenta mais amplo, na medida em que admite poderem adquirir a qualidade de sócio nas cooperativas de primeiro grau as comunidades de bens ${ }^{8}$, que não têm personalidade jurídica. A ausêncía da personalidade jurídica pode trazer sob ponto de vista do exercício dos direitos e do cumprimento das obri-

${ }^{5}$ A título exemplificativo assim sucede nas cooperativas de artesanato, de consumo e de habitação.

- De notar que quer na redacção anterior do Código Cooperativo, se previa, como regra geral, que os cooperadores fossem maiores de idade, admitindo-se que a legislaçâo complementar aplicável aos sectores previsse a atribuição da qualidade de sócio a menores de idade.

${ }^{7}$ São pessoas colectivas as associaçốes, as fundaçōes e as sociedades civis e comerciais nos termos do disposto no artigo $157 .^{\circ}$ do Código Civil.

${ }^{8}$ Como poderá ocorrer nas cooperativas agrárias a que alude o artigo 112 , da Lei de Cooperativas da Galiza. 
gações algumas dificuldades, admitindo-se por isso que, para ramo de cooperativa possam prever-se certas especificidades.

No que respeita às cooperativas de segundo grau, podem ser sócios, as sociedades cooperativas e os sócios de trabalho destas, assim como outras sociedades não cooperativas em que se verifique comunhão de interesses e necessidades. ${ }^{9}$

De notar ainda que, nas sociedades cooperativas da Galiza, além do estatuto do sócio em geral, o qual comparativamente com o estatuto dos cooperadores em Portugal iremos de seguida analisar, existem alguns easos de estatutos particulares, o mesmo é dizer, algumas normas específicas que se aplicam apenas àquelas categorias de sócios. Os regimes especiais previstos são: os sócios de trabalho ${ }^{10}$, os sócios à experiência ${ }^{11}$, os sócios excedentes ${ }^{12}$ e os sócios colaboradores ${ }^{13}$.

\subsection{Requisitos previstos no Código Cooperativo}

\subsubsection{Respeito pelos princípios cooperativos}

O artigo 3. ${ }^{\circ}$ do Código Cooperativo estabelece os princípios cooperativos, princípios estes, que foram formulados pela Aliança Cooperati-

\footnotetext{
"Assim acontccerá se os estatutos não o proibirem conforme resulta do artigo 18.1, 2 . parágrafo.

${ }^{10}$ No artigo 21 .da Lei de Cooperativas da Galiza admite-se a categoria de sócios de trabalho, neste caso os sócios adquirirão essa qualidade $\mathrm{em}$ virtude da prestação da sua actividade à cooperativa. A admissão destes sócios importa algumas especificidades nomeadamente, no que respeita à participação das perdas da cooperativa, caso em que são isentos de tal obrigação.

"Esta categoria de sócios, vem prevista no artigo 27. da Lei de Cooperativas da GaliZa, admite-se como regra que, possam ser admitidos sócios nestas condiçōes por um período năo superior a um ano. As várias alíneas deste artigo destinam-se a isentá-los do cumprimento de algumas obrigaçōes, como por exemplo a de realizar as entradas, e a de participar nas perdas.

${ }^{12} \mathrm{O}$ artigo 28 . da Lei de Cooperativas da Galiza admite que nalgumas cooperativas possa haver sócios excedentes, nos casos em que em que os sócios com causa justificada tenham solicitado por escrito à cooperativa a vontade de sair. Em relação a estes sócios não se thes garante o lucto.

${ }^{13} \mathrm{Em}$ relação a esta categoria de sócios estabelece o artigo 29. da Lei de Cooperativas da Galiza que os mesmos embora não possam realizar tolalmente o objecto social da cooperativa, possam colaborar com a cooperativa na sua prossecução. Remete-se para os estatutos de cada cooperativa o desenvolvimento da figura.
} 
va Internacional. ${ }^{14}$ Estas regras são aquelas a que quer na constituição, quer no funcionamento a cooperativa está sujeita, o que implica desde logo que todos os membros que pretendam entrar na cooperativa os respeitem integralmente.

Dentro dos sete princípios aí referidos, relacionam-se em especial com a aquisição da qualidade de cooperador o 1. e 3. ${ }^{\circ}$ princípios que estabelecem, respectivamente, a adesão livre e voluntária e a participação económica dos membros.

No que concerne à Lei de Cooperativas da Galiza, muito embora, não se proceda no texto da lei à enumeração dos princípios, como acontece na lei Portuguesa, concluímos que atento o disposto no artigo 1.4 a constituição e o funcionamento da cooperativa tem de ajustar-se a estes princípios.

\section{a) Princípio da adesão voluntária e livre}

O primeiro princípio estabelece a adesão voluntária e livre dos cooperadores à cooperativa. Princípio este, genericamente designado como "princípio da porta aberta". De acordo com este princípio podem aderir "todas as pessoas aptas a utilizar os seus serviços e dispostas a assumir as responsabilidades de membro, sem discriminações de sexo, sociais, políticas, raciais ou religiosas."

Desta natureza aberta das cooperativas resultam desde logo duas consequências: a primeira que tem a ver com a composição da cooperativa, ou scja com o número de membros ou cooperadores que dela fazem parte a cada momento, e que, como se conclui se pode apresentar instável. ${ }^{15}$ A segunda que deriva desta, é variação do capital, já que

\footnotetext{
"Destes principios resulta a essência da cooperativa enquanto pessoa colectiva diferente das demais, e que desde sempre inspiraram o movimento cooperativo.

${ }^{15}$ A doutrina portuguesa tem genericamente considerado este princípio com algumas limitaçôes, nomeadamente admitindo que en relação a algumas coopcrativas, dadas as suas necessidades e especilicidades de funcionamento, a livre adesão de membros não seja de admitir sem quaisquer restriçōes, referindo exemplificativamente o caso das coopcrativas de habitação. Defenden que se deve interpretar este princípio como una imposiçäo através da qual se procuram evitar limitaçós anbitrárias.
} 
a permanente entrada e saída (demissão) de cooperadores faz com o que o seu capital se apresente instável ${ }^{16}$.

Na Lei das Cooperativas da Galiza esta ideia de livre adesão e saída dos membros faz parte do próprio conceito de cooperativa, o que, conforme o disposto no artigo l. I é uma das características da sociedade cooperativa, que a diferencia das outras sociedades.

\section{b) Princípio da participação económica dos membros}

O terceiro princípio constante do artigo $3 .^{\circ}$ do Código Cooperativo dispõe o seguinte: "os membros contribuem equitativamente para o capital e controlam-no democraticamente. Pelo menos parte desse capital é, normalmente propriedade comum da cooperativa. Os cooperadores, habitualmente, recebem, se for caso disso, uma remuncração limitada pelo capital subscrito como condição para serem membros. Os cooperadores destinam os excedentes a um ou mais dos objectivos seguintes: desenvolvimento das suas cooperativas, eventualmente, através da criação de reservas, parte das quais, será indivisível, benefício dos membros na proporção das suas transacções com a cooperativa, apoio a outras actividades aprovadas pelos membros."

A primeira conclusão a retirar desta norma é que dela constam vários aspectos relacionados com a participação económica dos membros, mas nesta fase da nossa análise, apenas nos interessa a primeira parte do preceito que respeita à contribuiçấo que os membros estão obrigados a realizal para adquirirem a qualidade de cooperadores, e portanto ingressarem na cooperativa.

O desenvolvimento destes princípios relativos à participação económica dos cooperadores encontra-se no Código Cooperativo no capítulo III, sob o título "capital social, jóia e títulos de investimento" a que correspondem os artigos $18 .^{\circ}$ a $30 .^{\circ}$.

No que respeita à Lei de Cooperativas da Galiza, a primeira nota acerca da participação econónica dos membros é a de que esta matéria se encontra bastante mais desenvolvida ${ }^{17}$, o que resulta da consagração da cooperativa como uma verdadeira sociedade.

\footnotetext{
${ }^{16}$ Conforme resulta do princípio geral expresso no attigo 18." do Código Cooperativo.
} 


\subsubsection{Participação no capital social ${ }^{18}$ através da realização das entradas}

Os cooperadores para entrarem para cooperativa têm de realizar as suas entradas cuja soma perfaz o capilal social.

O legislador cooperativo estabeleceu no n. ${ }^{\circ} 2$ do artigo $18 .^{\circ}$ o montante mínino de capital, regra a que, em geral, estão sujeitas todas as cooperativas. ${ }^{19}$

De acordo com a norma esse montante não pode ser inferior a 2500 euros.

As entradas dos sócios destinam-se a completar o capital social, que é variável ${ }^{20}$ e potencialmente ilimitado.

O cooperador tem de entrar para a cooperativa com dinheiro, bens, direitos, trabalho ou serviços, segundo o disposto no artigo $21 .^{\circ}$ n. 1 do Código Cooperativo.

Cada cooperador tem de realizar no acto de admissão ${ }^{21}$ uma entrada mínima ${ }^{22}$ nos termos previstos no arligo $19 \%^{\circ}$.

O valor mínimo das entradas a realizar é fixado pela legislação complementar aplicável aos diversos ramos de cooperativas ou pelos estatutos. ${ }^{23}$

${ }^{17}$ Encontra-se no Capítulo $\mathrm{V}$ da Lei de Cooperativas da Galiza, a que correspondem os artigos 58 . a 71 .

${ }^{18}$ Apesar da ulilização da expressão, constata-se que o capital social adquire aqui contomos diversos daquele que apresenta no âmbito das sociedades comerciais e que são fixados no Código das Sociedades Comerciais. Com efeito, nas sociedades comerciais o capital social aparece associado à ideia de lucro, sendo am dos factores essenciais da sua determinação, o que não acontece nas cooperativas.

"Admite-se excepcionalmente, que outro possa ser o montante de capital social minimo se isso estiver previsto na legislação complementar dos ramos do sector cooperativo.

${ }^{20} \mathrm{O}$ facto do capilal social ser variável determina que por um lado para o aumentar năo seja necessária a tealização da escritura pública, conforme se exige para as sociedades comerciais (artigos 85. e seguintes do Código das Sociedades Comerciais), nem para a sua redução até ao limite mínimo fixado na lei é necessária a autorização judicial, nem a realizaçăo da escritura pública (artigo $850^{\circ}$ e $95.0^{\circ}$ Código das Sociedades Comerciais).

"Conforme resulta do artigo $22{ }^{\circ}$ do Código Cooperativo.

"Salvo no caso de se tratar de cooperador de responsabilidade ilimitada, conforme o $\mathrm{n}^{\circ}$ 3 do artigo 19." do Código Cooperativo.

${ }^{23}$ Verifica-se que em muitos dos ramos de cooperativas a cntrada mínima está fixada nos 100 euros, como sucede, por exemplo, nas cooperativals agrícolas e nas cooperativals de habitação e construção. 
Como princípio geral aplicável a todas as cooperativas o n. 2 do artigo 19. ${ }^{\circ}$ estabelece que as entradas mínimas não podem ser de valor inferior ao equivalente a três títulos de capital e metade do seu valor tem de ser obrigatoriamente realizado em dinheiro, nos termos do n. 2 do artigo 21. ${ }^{\circ}$ do Código Cooperativo.

O prazo máximo para realizar o capital subscrito é de cinco anos, conforme se lê no n. 3 do artigo $21 .^{\circ}$.

O Código Cooperativo admite que, relativamente ao capital social possam ser emitidos títulos representativos do valor desse capital, conforme o estatuído no artigo $200^{\circ}$, tendo nesse caso cada título o valor mínimo de 5 euros.

Quando a entrada seja realizada em bens, direitos, trabalho ou serviços a lei obriga a que o valor da respectiva entrada seja fïxado em assembleia de fundadores ou assembleia geral sob proposta da direcção, conforme o artigo $21 .^{\circ} \mathrm{n} .^{\circ} 5$ do Código.

$\mathrm{O}$ artigo $15^{\circ} \mathrm{n} .^{\circ} 1$ alínea e) do Código Cooperativo estabelece ainda que o valor do capital social, das entradas subscritas por cada sócio, e da forma de as realizar são aspectos que tem obrigatoriamente de constar dos estatutos da cooperativa.

Para além de ser um dos requisitos sem o cumprimento do qual o cooperador não chega a adquirir tal qualidade, a participação no capital social marca também a responsabilidade do cooperador. ${ }^{24}$ Regra geral, a responsabilidade dos cooperadores é limitada ao capital subscrito, conforme o disposto no artigo $35 .^{\circ}$ do Código Cooperativo. Admite-se no entanto, que os estatutos possam determinar que a responsabilidade dos seus membros possa ser ilimitada ou seja limitada quanto a uns e ilimitada quanto a outros, sem que isso viole os princípios cooperativos, em especial o da gestão democrática dos membros. ${ }^{25}$

Na Lei de Cooperativas da Galiza, concluímos que, só adquirirá a qualidade de sócio aquele que realizar a entrada contribuindo assim para a formação do capital social, de acordo com o valor fíxado nos estatu-

\footnotetext{
${ }^{24}$ A ideia de que a entrada para a cooperativa acarreta a assunção de responsabilidade pelos cooperadores decorre do primeiro princípio cooperativo onde se eslatui que poderão ingressar na cooperativa as pessoas dispostas a assumir as responsabilidades de membro. A participação no capital social determina o nivel de responsabilidade dos cooperadores.

"Que a lei garante através da regra um homem um voto.
} 
$\operatorname{tos}^{26}$, conforme resulta dos artigos $19.1,2 .^{\circ}$ parágrafo, e 58. e 59.. A participação no capital social pode ser voluntária ou obrigatória, e admitese que, possam ser emitidos títulos nominativos não negociáveis. $O$ valor das entradas e portanto da participação obrigatória na cooperativa será variável conforme os estatutos, mas em todo caso deverá ser no mínimo de $25 \%$ do valor total no momento da entrada para a cooperativa, conforme o artigo 59.1. e 2. da Lei de Cooperativas da Galiza.

\subsubsection{Realização da jóia de admissão}

Além da realização das entradas nos termos previstos, prevê o artigo $25^{\circ}$ do Código Cooperativo a possibilidade dos estatutos da cooperativa preverem a exigência de uma jóia aos cooperadores. Trata-se por isso de uma faculdade da cooperativa a fixação ou não deste montante que os sócios entregarão à cooperativa no acto de admissão.

Esta jóia pode ser paga de uma só vez ou em prestações periódicas, e tem sido utilizada como meio de limitar a adesão voluntária e livre dos membros.

No que respeita ao valor a cobrar a título de jóia, deve ser fixado pelos estatutos, destinando-se a integrar as reservas obrigatórias da cooperativa $^{27}$.

O Código Cooperativo deixou de fixar um montante máximo de jóia como fazia na redacção inicial.

De acordo com o artigo $15 .^{\circ}$ n. 1 alínea e) consta obrigatoriamente dos estatutos o montante das jóias, se estas forem exigíveis.

No artigo 19. I da Lei de Cooperativas da Galiza, também se admite que para adquirir a qualidade membro da cooperativa, tenha o sócio de prestar a quota de ingresso, conforme o estabelecido e aprovado pela assembleia geral nos termos do artigo $31.1 \mathrm{~h}$ ) da referida lei.

\subsection{Requisitos previstos na legislação complementar aplicável aos diversos ramos do sector cooperativo}

\footnotetext{
${ }^{26}$ De acordo com o artigo 59.1 a entrada que os sócios irăo realizar pode ser diferente para os vários tipos de sócios que a I ei de Cooperativas da Galiza prevê.

${ }^{27}$ Que de acordo com os artigos 69." e 70. do Código Cooperativo são a reserva legal e a reserva para educação e formação cooperativas.
} 
Além dos requisitos gerais analisados no ponto anterior, o artigo 31."n. 1 do Código Cooperativo admite que para calda cooperativa possam existir requisitos próprios, específicos, em função da actividade ou do objecto a que se dedica. Sem pretender fazer aqui uma enumeração exaustiva de todas as cooperativas sujeitas a legislação complementar sempre se referirão alguns exemplos.

Esses requisitos específicos constantes da legislação complementar podem dizer respeito, por exemplo, às características pessoais dos membros.

Assim, no que concerne às características dos membros, por exemplo nas cooperalivas agrícolas ${ }^{28}$ os cooperadores deverão exercer actividades agrícolas, agro-pecuárias, florestais ou actividades relacionadas ou conexas com estas.

Nas cooperativas de habitação ${ }^{29}$ os membros devem associar-se com vista à satisfação de necessidades habitacionais sem fim lucralivo.

Também nas cooperativas de ensino superior ${ }^{310}$, se exigem especiais requisitos dos seus membros devendo os docentes que a integram e mesmo os alunos possuir determinadas características ou habilitações legais definidas pelo Ministério da Educação.

No que respeita aos aspectos da participação económica dos membros pode também como concluímos, a legislação complementar para os ramos das cooperativas estabelecer o montante do capital social, o valor das entradas, a forma de as realizar, e o valor da jóia.

Da análise realizada concluímos haver também, na Lei de Cooperativas da Galiza requisitos distintos consoante o ramo da cooperativa a cujo membro pretende aderir ${ }^{31}$, e que dirão respeito por exemplo, ao aspecto profissional, à titularidade de certos bens, à posse de determinada formação ou qualificação, ou até requisitos geográficos.

\subsection{Requisitos previstos nos estatutos da cooperativa}

\footnotetext{
Conforme o Decreto-Lei $335 / 99$ de 20 de Agosto.

${ }^{20}$ Cujo regime consta do Decreto-I ei $502 / 99$ de 19 de Novembro.

${ }^{30}$ Nos termos do Decreto-I ei $441-\mathrm{A} / 82$ de 6 de Novembro.

${ }^{31}$ Com uma diferença, enquanto na Lei de Cooperativas da Galiza a regulamentaçäo dos vários ramos de cooperativas laz parte desta, no caso Português, o Código Cooperativo apenas trata das normas gerais aplicáveis a todas as cooperativas, deixando para legislação avulsa o tratamento de cada um dos ramos de cooperativas.
} 
A referência ao conteúdo dos estatutos da cooperativa encontra-se no artigo $15 .^{\circ}$ do Código Cooperativo. Da análise da norma concluímos que há requisitos essenciais que tem de integrar obrigatoriamente os estatutos, ${ }^{32}$ havendo outros de natureza não essencial.

Os requisitos que dizem respeito às condições de admissibilidade dos cooperadores encontram-se no n. 2 da norma e têm esta natureza de requisitos não essenciais, o que significa que cabe à cooperativa, em especial aos membros fundadores decidir se pretendem ou não inserir disposiçōes acerca destas matérias nos estatutos.

Contudo, uma vez inseridas nos estatutos normas para disciplinar as condições de admissibilidade passam a ser obrigatórias para todos os que pretendam aderir àquela cooperativa.

Admite-se que, os estatutos possam incluir disposições sobre as condições de admissão, suspensão, exclusão, demissão, direitos e deveres dos cooperadores, e bem assim sobre as sanções e as condições da suá aplicação, e sobre a distribuição dos excedentes pelos seus membros, conforme consta das várias alíneas do n. 2 do artigo $15 .^{\circ}$ do Código Cooperativo.

Estas condições de admissibilidade que integram os estatutos da cooperativa podem ser também utilizadas para limitar o princípio da adesão volıntária e livre dos cooperadores.

Também na Lei das Cooperativas da Galiza, no artigo 19.1 se estabelece que o candidato que solicita a admissão à cooperativa deve preencher os requisitos estatutários, sem que, contudo os estatutos possam impedir a entrada dos sócios por motivos ilícitos ou inconstitucionais. O artigo 14 da Lei de Cooperativas da Galiza, estabelece o conteúdo mínimo dos estatutos e o ponto 1.7) prevê exactamente a necessidade de os estatutos tratarem desta matéria, quando se refere às condições e requisitos para adquirir a qualidade de sócio.

\footnotetext{
${ }^{32}$ De acordo com o n." I do artigo: a denominação da cooperativa e a localização da sede; o ramo do sector cooperativo a que pertence, bem como o objecto da actividade; a duraçấo da cooperativa se não for por tempo indeterminado; os órgãos da cooperativa; c o montante do capital social inicial, o montante das jóias, se existir, o valor dos tílulos de capital, o capilal mínimo a subserever por cada cooperador e forma da sua realização. ${ }^{33}$ A distinçäo importa essencialmente no que respeita às consequências, se faltarem os requisitos esscnciais o acto de constituição da cooperativa é nulo, nos termos previstos no artigo 294." do Código Civil. Ao passo que se faltarem os outros requisitos, muito embora, a disciplina do regime jurídico da cooperativa possa năo estar completa, não está em questăo a sua existência.
} 
Pelo exposto, podemos concluir que atento este regime, podem os estatutos limitar a entrada de sócios na medida em que estabeleçan outros requisitos que condicionem esta entrada.

\subsection{Pedido de admissão à direcção da cooperativa}

Finalmente condiciona a aquisição da qualidade de cooperador o pedido de admissibilidade à direcção da cooperativa. ${ }^{34}$

A direcção é o órgão de administração e representação da cooperativa e nessa medida, para além de outras competências não expressamente previstas no artigo $56^{\circ}$ do Código Cooperativo, cabe-lhe em especial, deliberar sobre a admissão de novos membros, conforme previsto na alínea d).

A propósito deste poder atribuído à direcção, a principal questão que se coloca resulta da possibilidade de a direcção poder recusar a admissão de novos membros, o que parece contrariar os princípios cooperativos, em particular, o princípio da adesão voluntária e livre.

Assim, deve a direcção ponderar bem a situação de recusa de adesão do membro. À luz do referido princípio, deverá recusar apenas a entrada em situações em que não sejam cumpridos os requisitos estatutários, ou as condições da legislação do sector cooperativo.

Em qualquer dos casos referidos pode a direç̧ão recusar a admissão. Se a direç̧ão recusar a admissão de um membro cabe recurso dessa deliberação para a assembleia geral, ${ }^{36}$ a primeira a realizal posteriormente à deliberação que recusa a entrada do candidato. A logitimidade para recorrer a lei atribuía ao candidato e aos outros membros da cooperativa, conforme o n. 2 e 3 do artigo $31 .^{\circ}$ do Código Cooperativo.

A Lei de Cooperativas da Galiza também determina o cumprimento deste requisito para a aquisição da qualidade de membro. Com efeito, aquele que pretenda entrar como sócio numa cooperativa tem de

\footnotetext{
${ }^{4}$ A matéria relativa à direç̧ão, vem tratada nos artigos $55 .^{\circ}$ e seguintes do Código Cooperativo.

${ }^{35}$ Como poderá acontecer por exemplo se por uma cooperativa de produção de leite atingiu a quota de produção, ou quando o cooperador tenha já pertencido a outra cooperativa e o seu comportamento seja reprovável.

3/ O funcionamento da assembleia geral como instância de recurso nesta matéria decone da norma que fixa as suas competências, alínea 1) do artigo $49 .{ }^{\circ}$ do Código Cooperalivo.
} 
solicitar por escrito, ao órgão de administração (o Conselho Reitor) da sociedade a sua admissão que deverá fundamentadamente decidir, a admissão no prazo máximo de dois meses, comunicando-o ao sócio e publicando no quadro de anúncios da cooperativa, esse facto, ou através de outro meio que os estatutos prevejam. Esgotado este prazo, sem manifestação da resolução considera-se que a admissão foi recusada, conforme o artigo 19.2 da Lei de Cooperativas da Galiza, o que nos permite concluir pela existência de uma recusa tácita ${ }^{37}$.

Tal como no sistema português, contra a recusa de admissão pode o candidato recotrer no prazo de um mês a contar da notificação ou do momento em que o prazo expirou para o Comité de Recursos ou na sua falta, para a Assembleia geral ${ }^{38}, 19.22^{\circ}{ }^{\circ}$ parágrafo. Em caso de recusa da admissấo admite-se sempre a audiência do interessado.

\section{Direitos dos cooperadores}

Os direitos dos cooperadores vêm referidos no artigo $33 .^{\circ}$ do Código Cooperativo. Da análise da norma resulta que a referência a estes direitos não é taxativa, pois o legislador utiliza a expressão nomeadamente.

Os dircitos que vêm referidos no artigo são, por isso, os principais, os mais relevantes, aqueles que definem e delimitam o estatuto do cooperador na cooperativa a que pertence. Neste artigo tratam-se apenas os direitos de carácter pessoal. Procederemos à análise de cada um deles, não sem antes notar que a propósito desta matéria dispõe o artigo 22. da Lei de Cooperativas da Galiza, que além dos direitos que prevê, admite também a possibilidade de os sócios poderem ter outros direitos para além destes, em especial, os que resultarem da lei e dos estatutos ou os que forem validamente adoptados pelos órgãos sociais.

Relativamente aos direilos que estão previstos admite-se que serão exercidos em conformidade com o disposto nas normas legais, nos estatutos e nas decisões dos órgãos sociais (artigo 22.2.).

\footnotetext{
${ }^{37}$ Neste aspecto o Código Cooperativo e a Lei de Cooperativas da Galiza năo estão em sintonia, pois de acordo com o dircilo Português a admissão do sócio não requer qualquer fundamentação ou motivação, ao passo que na lei da Galiza, se exige essa fundamentaçăo para a admissão.

${ }^{38}$ Devendo o recurso ser apreciado na primeira reunião que se realize posteriormente à decisäo.
} 


\subsection{Participar e votar na assembleia geral}

Cada cooperador tem o direito a participar e a votar na assembleia geral. Este órgão é segundo o arligo 44." o órgão supremo da cooperativa, sendo as suas deliberações obrigatórias para os restantes órgãos.

Participam na assembleia geral todos os cooperadores que estejam no pleno gozo dos seus direitos.

As matérias que são da sua competência exclusiva, e portanto não delegáveis, são as previstas no artigo $49 .^{\circ} \cdot{ }^{39}$ Cabe aos cooperadores a manifestação de vontade e a deliberação sobre os aspectos principais do destino da cooperativa.

Estabelece o artigo 51. $\mathrm{n}^{\circ} 1$ que a cada cooperador cabe um voto ${ }^{40}$, independenternente da participação de que disponha no capital social, sendo esta norma uma extensão do princípio cooperativo da gestão democrática pelos membros da cooperativa.

Na Lei de Cooperativas da Galiza, no artigo 22.1.b) também se prevê a possibilidade do sócio participar, apresentando propostas, manifestando a sua opinião e votando nas reuniões dos órgãos sociais de que seja membro. No que respeita à votação a realizar na assembleia geral também encontramos a ideia de que a cada sócio corresponde um voto conforme o disposto no artigo 36.1 da Lei de Cooperativas da Galiza.

\subsection{Eleger e ser eleito para os órgãos da cooperativa}

\footnotetext{
${ }^{39}$ Elcição e destituiçăo dos membros dos órgãos; apreciação e votação das contas e da respectiva certificação; apreciação e votação do orçamento e do plano de actividades para o exercício seguinte; fixação das taxas de juro a pagar aos cooperadores, aprovação da distribuição dos excedentes; alteração dos estatutos e dos regulamentos internos; aprovação da fusão e cisão da cooperativa; aprovação da dissolução voluntária da cooperativa; aprovação da filiação da cooperativa en unoes, federaçôes e confederações; deliberação sobre a exclusão de cooperadores e perdas de mandato dos órgãos; funcionamento como instância de recurso quanto à recusa de entrada de novos sócios, quer quanto às sançôes aplicadas; fixação da remuneração dos membros dos ógãos sociais; decisão sobre o exercício da açä́o civil e penal; apreciação e votação das matérias previstas na legislaçăo complementar ou nos estatutos.

4) $\mathrm{O}$ voto pode ser realizado na assembleia geral, por correspondencia nos termos do artigo 52. ou por representação nos termos do artigo 53." do Código Cooperativo.
} 
Um outro direito que a título exemplificativo o legislador refere é o previsto na alínea b) do n. 1 do artigo $33 .^{\circ}$ que consiste no direito de eleger e de ser eleito para os órgãos da cooperativa.

Esta matéria encontra-se desenvolvida nos artigos $40 .^{\circ}$ e $42 .^{\circ}$ do Código onde se trata respectivamente da eleição dos membros dos órgãos sociais e das incompatibilidades.

Estabelece a primeira das normas que os membros dos órgãos sociais são eleitos de entre os cooperadores.

Regra geral, os órgãos serão eleitos por um período de quatro anos, se outro mais curto não for previsto, o que significa que o $\mathrm{n}^{\circ} \mathrm{I}$ do artigo $40 .^{\circ}$ estabelece o período máximo de duração dos mandatos. Por outro lado, o artigo $15 .^{\circ}$ admite que os estatutos possam fixar a duração dos mandatos dos titulares dos órgãos sociais, conforme a alínea c) do n. 2 , caso em que, só poderão ter duração inferior a quatro anos.

O n. 3 do artigo $40 .^{\circ}$ admite ainda que, os estatutos possam limitar o número de mandatos para qualquer dos órgãos.

O artigo 42..$^{\circ}$ proíbe que os cooperadores sejam simultaneamente membros da mesa da assembleia geral, da direcção, do conselho físcal ou dos outros órgãos que eventualmente os estatutos prevêem.

Assim como, não permite que sejam membros do mesmo órgão social com mais de vinte membros, ou sejam simultanearnente membros da direcção e do conselho fiscal os cônjuges ou os unidos de facto.

O Código admite que quer os estatutos ${ }^{41}$, quer a assembleia, posteriormente, possam fixar uma retribuição para os membros dos órgãos, artigo $43 .^{\circ}$ n. 6 e alínea $m$ ) do artigo $49 .^{\circ}$.

Também os sócios que façam parte de uma sociedade cooperativa na Galiza, poderão usufruir deste mesmo direito nos termos do disposto no artigo 22.1.a) da Lei de Cooperativas da Galiza, que não é um direito absoluto porquanto para alguns órgãos se exigem requisitos específicos (artigo 39.4), e mesmo incompatibilidades (artigo 48.).

\subsection{Requerer informações aos órgãos da sociedade}

Este direito dos cooperadores vem previsto na alínea c) do artigo 33. . De acordo com o exposto no artigo em referência podem os coope-

"Decorre lambém dessas normas a possibilidade de os estatutos poderem proibir a remuneração dos membros dos órgãos. 
radores requerer informações aos órgãos, examinar a escrita e as contas nos períodos e condiçóes fixados pelos estatutos ou pela assembleia geral ou direç̧̃̃o.

Relativamente ao exercício deste direito pelos cooperadores pouco diz o Código Cooperativo. Com efeito, as indicações que fornece constam apenas dos n. ${ }^{\circ}$ s 2 e 3 do artigo $33 .^{\circ}$.

Refere o n. ${ }^{\circ} 2$ que das deliberações da direcção acerca do exercício do direito à informação cabe recurso para a assembleia geral.

$\mathrm{O}$ n. ${ }^{\circ} 3$, por seu lado, tem uma aplicação específica, pois refere que o exercício do direito à informação é limitado nas cooperativas de crédito em virtude das restrições decorrentes do sigilo bancário.

No que se refere ao exercício do direito, ao mesmo aplica-se enquanto direito subsidiário (artigo 9. ${ }^{\circ}$ do Código Cooperativo) as normas do Código das Sociedades Comerciais onde se prevêem as modalidades do exercício do direito à informação: direito mínimo à informação ${ }^{42}$ - artigo $288 .^{\circ}$; direito às informações preparatórias da assembleia

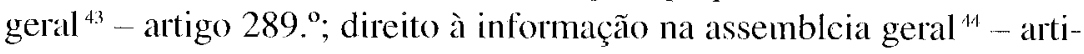
go $290 .^{\circ}$; direito colectivo à informação ${ }^{45}$-- artigo $291 .^{\circ}$; e o inquérito

${ }^{42}$ De acordo com este artigo poderão os sócios cujo capital perfaça $1 \%$ do capital e desde que aleguem motivo justificado consultar na sede da sociedade: os relatórios de gestão c os documentos contabilísticos; as convocatórias, as actas e as listas de presenças; o montante das remunerações pagas aos membros do órgão de administração e de fis calização; o montante das retribuições pagas aos cinco funcionários da ompresa com remuneraçōes mais elevadas.

${ }^{43}$ Durante os 15 dias anteriores à data da assembleia geral os sócios podem consultar na sede da sociedade os nomes completos dos membros dos órgãos de administração e de fiscalização e da mesa da assembleia geral; a indicação de outras sociedades em que os membros dos órgãos sociais exerçam cargos; as propostas de deliberação a apresentar à assembleia geral pelo órgão de administração; o nome e a identificação das pessoas que fïguram nas listas para a eleição dos órgãos sociais, quando for esse assunto constar da ordem do dia; quando se tratar da assembleia geral anual, o relatório de gestão, as contas do exercício, e demais documentos de prestação de contas.

"4a assembleia geral o sócio pode também requerer informaçōes mas aggora confinadas apenas aos assuntos que serão sujeitos a deliberação de forma que tal informação thes permita formar uma opinião fundamentada.

4. De acordo com este artigo o direito à informação pode ser exercido por sócios que detenham $10 \%$ do capital social, caso em que podem solicitar por escrito ao órgão de administração informações sobre os assuntos sociais, devendo este órgäo responder lambém por escrito. 
judicial ${ }^{46}$ - artigo $292 .^{\circ}$. A aplicação destas normas pressupõe, a sua necessária adaptação às especificidades da cooperativa.

Na Lei de Cooperativas da Galiza, constatamos que no artigo 22.1.d) também se estabelece o direito dos sócios terem acesso à informação de que necessitam para o exercício dos seus direitos e para o cumprimento das suas obrigações. As condições do exercício deste dircito vêem tratadas no artigo 23.

Encontra-se assim, consagrado como direito individual de todos os sócios, e de forma bastante mais desenvolvida, pois como afirmamos, no Código Cooperativo Português apenas se consagra o direito à informação remetendo-se o seu exercício para o Código das Sociedades Comerciais. Assim, a todos os sócios é assegurado o direito a obter informações sobre o funcionamento da sociedade nos termos decorrentes da lei dos estatutos e das decisões da assembleia geral.

A obrigação de informar cabe ao órgão de administração da sociedade, o Conselho Reitor.

O ponto 2. do artigo 23. nas alíneas a) a l) estabelece o conteúdo mínimo do direito à informação que comporta genericamente o acesso a vários documentos (estatutos, regulamentos internos); o direito de examinar os livros da sociedade (actas, registo dos sócios); o direito a obter cópias, se o solicitar, das deliberações da assembleia geral, o direito à informação preparatório da assembleia geral (essencialmente informação de carácter contabilístico e a possibilidade de pedir esclarecimentos); pedir informações por escrito acerca do funcionamento da cooperativa; exercer por escrito e conjuntamente com outros sócios o direito colectivo à informação.

Admite-se que possa não ser prestada toda a informação solicitada quando de forma grave estejam em perigo os legítimos interesses da sociedade cooperativa, podendo nesse caso o sócio lançar mão a vários recursos e mesmo impugnar judicialmente a decisão, conforme o ponto 3. e 4. do antigo 23 .

\subsection{Requerer a convocação da assembleia geral}

\footnotetext{
*o $O$ sócio que nalguns casos veja negada a informaçăo solicitada à sociedade pode rocorrer ao tribunal para efectivar o seu dircito à informação, de modo a que este ordene um inquérito à sociedade.
} 
Na alínea d) do artigo $33 .^{\circ}$ prevê-se outro direito dos cooperadores que é o de requerer a convocação da assembleia geral nos tcrmos definidos nos estatutos e a possibilidade de requerer a convocaçáo judicial.

Pode o cooperador requerer uma assembleia geral extraordinária nos termos previstos no artigo $45 .^{\circ}$ do Código Cooperativo. Do n. 3 do artigo $45 .^{\circ}$ e do artigo $46 .^{\circ}$ n. 2 a) resulta que a reunião scrá convocada pelo presidente da mesa assembleia geral, pelo que, embora não referido expressamente, o requerimento do pedido da realização da assemblcia geral the deverá ser dirigido.

Podem os cooperadores requerer uma assembleia geral extraordinária, a par da direcção ou do conselho fiscal quando o pedido for teito por pelo menos $5 \%$ dos membros da cooperativa, no mínimo de 4 cooperadores. Admite-se contudo que os estatutos da cooperativa ou a legislação complementar do sector cooperativo possam dispor de maneira diferente sobre o exercício deste direito, tendo a norma carácter supletivo.

A assembleia extraordinária requerida nos termos referidos na lei, nos estatutos ou na legislação complementar, que venha a ser recusada ou que não venha a ser convocada, pode ser convocada judicialmente.

Na Lei de Cooperativas da Galiza este direito dos sócios não aparece expressamente previsto no elenco do artigo 22., no entanto, constata-se que podem os sócios solicitar a convocação de uma asscmbleia geral extraordinária nos termos do ponto 3. do artigo 33., quando a reunião for pedida por 100 sócios ou por sócios que representem $20 \%$ do total dos votos.

Também se admite neste regime a possibilidade de o sócio recorrer à convocatória judicial da assembleia geral.

\subsection{Apresentar a sua demissão}

O úllimo dos direitos que vem enunciado no artigo 33.”, na alínea e) é o direito que assiste a todos os cooperadores de apresentarem a sua demissão.

As condições do exercício deste direito vêem reguladas no artigo 36. ${ }^{\circ}$ do Código.

A primcira nota é que este regime da demissão tem carácter supletivo, pois o alrtigo admite a possibilidade de os estatutos disporem de 
maneira diferente, estabelecendo regras ou condições sobre o exercício do direito. Sem que no entanto, possam limita-lo ou suprimi-lo, n. 2 do artigo $36 . \%$

Se dos estatutos não constar outro regime os cooperadores podem solicitar a sua demissão no fỉm de um exercício social. Deverão cumprir un pré-aviso de 30 dias, admitindo-se no entanto a responsabilidade dos cooperadores pelo cumprimento das obrigações como membros da cooperativa, o que quer dizer que até à data em que se efectiva a demissão os cooperadores estão vinculados a todos os deveres legais e estatutários.

A norma em referência não refere a quem é apresentado tal pedido, no entanto entendemos que, se cabe à direç̧ão decidir sobre a admissão dos membros, também lhe deverá ser atribuída a competência no que concerne à demissão dos cooperadores.

Se o membro solicitar a sua demissão tem direito a que the seja reslituído o montante dos títulos de capital realizado, segundo o seu valor nominal, o que deverá acontecer no prazo máximo de um ano, se outro não for estatutariamente previsto, $11 .{ }^{\circ} 3$ do artigo $36 .^{\circ}$.

De acordo com o n. ${ }^{\circ} 4$ do mesmo arligo, além deste valor tem o sócio o direito a receber na proporção da sua participação no capital, os juros relativos ao último exercício e ainda a quota-parte dos excedentes e as reservas que sejam repartíveis. Admitindo-se que em caso de perdas demonstradas no exercício em que surgiu o direito ao reembolso, possa o sócio receber menos do que o valor que efectivamente teria direito a receber, devendo, neste caso, os montantes ser reduzidos proporcionalmente ao valor das perdas.

No regime das cooperativas da Galiza o direito de sair da sociedade, faz parte do próprio conceito de cooperativa, motivo pelo qual não vem elencado no artigo 22. como direito dos sócios.

Com efeito, quando analisamos o conceito de cooperativa constante do artigo 1.1., conclúmos que o sócio não só pode entrar livremente para a cooperativa como dela sair quando desejar.

Neste regime das cooperativas da Galiza, é no artigo 20. que vem tratada a matéria da saída voluntária do sócio, admitindo-se ainda que, os estatutos possam tratar deste assunto, conforme o artigo 14.1.7).

A regra geral é que o sócio possa sair da cooperativa a qualquer momento ou seja, quando o descjar. Devendo para esse efeito avisar por 
escrito o órgão de administração. Em relação ao prazo de aviso prévio o ponto 1 . do artigo $20 .^{\circ}$ remete para o previsto nos estatutos, fixando, em todo o caso, como limite máximo um ano.

O incumprimento do pré-aviso pelo sócio pode dar lugar à indemnização pelos prejuízos e danos causados à cooperativa.

No ponto 2. do artigo 20. admite-se que os estatutos possam conter o compromisso do sócio não sair da sociedade voluntariamente antes do fím do exercício em curso, excepto quando ocorra para o sócio uma causa que o justifique, ou antes de decorrido certo tempo desde da sua entrada para a sociedade, que, ainda assim, não poderá ser superior a 10 anos.

No ponto 3. apontam-se algumas siluações que constituem justa causa para a saída voluntária do sócio, nestes casos a saída é sempre livre, pois não se exige que nestes casos o sócio continue ligado à sociedade.

O sócio que saia da cooperativa por sua livre vontade com causa ou sem ela, tem direito a receber o valor com que entrou para o capital social nos termos estabelecidos nos estatutos, conforme o disposto na alínea f) do artigo 22.1. e lambém do ponto 1. do artigo 64. da Lei de Cooperativas da Galiza ${ }^{47}$. Em todo o caso no prazo máximo de 5 anos a contar da data da saída, nos termos do artigo 64.4. da referida lei.

\subsection{Outros direitos previstos no Código}

Além dos direitos que expressamente se prevêem no artigo que analisamos resultam de outras normas, em especial, dos princípios cooperativos previstos no artigo $3 .^{\circ}$, outros direitos ligados à participação económica dos membros, entre os quais se destacam o direito a receber uma remuneração pelo capital subscrito e o direito a receber os excedentes, que em seguida analisaremos. Do Código Cooperativo resultam ainda outros direitos.

\subsubsection{Direito a receber uma remuneração pelo capital subscrito}

\footnotetext{
"Constata-se a possibilidade de ser dedwido ao sócio parte do valor do capital subs. crito, nomeadamente tatando-se de saída por expulsão, caso em que a dedução näo pode ultrapassat $30 \%$ nem os $20 \%$ se a saída for sem causa justificada.
} 
Um dos direitos dos cooperadores que se relaciona com a participação económica dos membros é poderem receber uma remuneração pelo capital que subscreveram para entrar para a cooperativa, e tal acontecerá se os estatutos o previrem.

Da análise do artigo $3 .^{\circ}$ do Código a principal ideia é a de que essa remuneração pelo capital subscrito tem carácter limitado. Acresce ainda que normalmente ou habitualmente será paga aos cooperadores, mas pode não ser, como decorre da expressão empregue pelo legislador "se for caso disso".

Relativamente ao juro a receber pela subscrição do capital resulta que, (juem tem competência para fixar a taxa é a assembleia geral, conforme a alínea e) do artigo $49 .^{\circ}$ que fixa a competência exclusiva da assembleia geral.

Por outro lado, quando numa cooperativa estiver consagrado este direito deverá ser cumprido antes da distribuição dos excedentes aos membros, conforme resulta do $\mathbf{n}^{\circ} 1$ do artigo $73 .^{\circ}$ do Código Cooperativo.

De acordo com os princípios cooperativos, e em especial o terceiro princípio, resulta que, a existir distribuição de juros pelo capital subscrito esse montante será limitado.

O Código não fixa nenhum valor máximo desse juro, mas apenas o n. 3 do artigo $73 .^{\circ}$ refere que, se estes juros forem pagos, o seu valor global não poderá exceder $30 \%$ dos resultados líquidos anuais.

Do exposto constata-se que esta é apenas mais uma forma a que a cooperativa pode lançar mão para distribuir os seus resultados.

Em caso de demissão ou exclusão o cooperador tem direito a receber o capital investido e os respectivos juros, artigo $36 .^{\circ}$ n. 3 e n. 4 e 37. ${ }^{\circ}{ }^{\circ} 9$ do Código Cooperativo.

Nas cooperativas da Galiza, e por força do previsto na alínea f) do artigo 22.1. têm os sócios o direito a receber um juro pelas entradas que realizaram, independentemente de existir um exercício com resultado positivo. Embora a lei não diga exactamente em que termos o direito será exercido pelos sócios, há sempre a considerar o que estiver fixado pelos estatutos, e também a deliberação da assembleia geral sobre esta matéria, conforme o artigo 60. e 61. da Lei de Cooperativas da Galiza. 


\subsubsection{Direito aos excedentes}

Em relação a este direito que assiste aos cooperadores, convém referir que o sistema económico das cooperativas é diferente do das sociedades comerciais. A primeira nota distintiva tem a ver não só com a natureza jurídica da cooperativa, enquanto pessoa colectiva, distinta das sociedades comerciais, como também, com os fïns que presidem à sua constituição.

Com efeito, enquanto para a sociedade comercial é um pressuposto da sua existência o lucro para distribuir pelos sócios, na cooperativa este não é um pressuposto nem da sua constituição, nem da sua existência.

De resto, da noção de cooperativa está ausente a ideia de lucro, pois no artigo $2 .^{\circ}$ do Código refere-se expressamente que as cooperativas visam "sem fins lucrativos" a prossecução dos seus objectivos. ${ }^{48}$

Conclui-se desta forma, existir uma subalternização do factor económico em relação aos fins prosseguidos pela cooperativa, assentes na entreajuda dos seus membros através da qual satisfazem as suas necessidades que juntamente com o respeito pelos princípios cooperativos preenchem o ideal cooperativo.

O direito a receber os excedentes não é um direito essencial dos cooperadores, nem um direito que a lei se preocupa em garantir a todos os membros, como faz nas sociedades comerciais, onde o direito ao lucro é um dos principais direitos dos sócios.

Este direito existirá para os cooperadores na exacta medida em que for fixado nos estatutos, sendo as normas da distribuição dos excedentes, uma daquelas que devem vir tratadas nos estatutos, conlorme a alínea e) do n. 2 do artigo $15^{\circ}$ do Código Cooperativo.

Admite-se que possam existir excedentes, e se existirem, uma das finalidades poderá ser a distribuição pelos cooperadores, conforme venha a ser decidido pela assembleia geral, nos termos do que resulta do artigo $49 .^{\circ}$ f) do Código Cooperativo.

Assim cabe aos cooperadores decidir qual o destino ou a utilização a dar aos excedentes, e que segundo o artigo $3 .^{\circ}$ do Código poderão ser

${ }^{48}$ De notar desde logo que o legislador cooperativo na esteira do que alirmamos nem sequer lhe chama lucio como o legislador societário, antes opta pela expressăo excedentes. 
a aplicação para o desenvolvimento da cooperativa; para constituição de reservas; ou para actividades aprovadas pelos membros.

$\mathrm{O}$ artigo $73 .^{\circ}$ do Código Cooperativo admite que, os excedentes anuais líquidos, que restarem depois de pagos os juros pelos títulos de capital, e da afectação às reservas, possam ser distribuídos aos cooperadores.

No entanto não se poderão distribuir excedentes, se houver prejuízos resultantes dos exercícios anteriores, ou se tal valor for necessário para reconstituir a reserva legal, conforme o previsto no n. 2 do artigo 73. ${ }^{\circ}$ do Código Cooperativo.

O cooperador tem direito a receber a sua quota-parte nos excedentes em caso de demissão, artigo $36^{\circ}$ n. $^{\circ} 4$ do Código Cooperativo.

A Lei de Cooperativas da Galiza, sendo a cooperativa configurada como uma sociedade o direito ao lucro, faz parte do próprio conceito. Com efeito, toda a actividade desenvolvida pelos sócios é na perspectiva de chegarem ao lucro para que $\mathrm{p}$ mesmo venha a ser distribuído por todos, conforme o artigo 1.1 da Lei de Cooperativas da Galiza.

Pelo exposto um dos direitos essenciais do sócio é aquele que vem referido no artigo 22.1.e) o de receber o "retorno cooperativo". Assim, caso a sociedade apresente lucros os sócios tem direito a recebê-los, isto é se em concreto a assembleia não os destinar por exemplo, à constituição de reservas, conforme o artigo 67. da Lei de Cooperativas da Galiza. Os lucros serăo distribuídos proporcionalmente pelos sócios em função das actividades e operaçôes realizadas, e não em função da participação no capital, número 3 . do artigo referido.

\subsubsection{Direito a utilizar os bens e os serviços produzidos pela cooperativa}

Outro dos direitos que resulta do regime do Código Cooperativo, e que também não vem previsto no artigo $33 .^{\circ}$ que trata desta matéria é o direito a utilizar os bens e os serviços produzidos pela cooperativa.

Este direito decorre da própria noção de cooperativa (n. ${ }^{\circ} 1$ do artigo $2 .^{\circ}$ ) e também dos princípios cooperativos (artigo 3.\%), em especial, o primeiro princípio onde se diz que as cooperativas são pessoas colectivas "abertas a todas as pessoas aptas a utilizar os scus serviços", mas também assentes na autonomia, e independência e intercooperação dos seus membros. 
Nas Cooperativas da Galiza, resulta por um lado do próprio conceito de cooperativa, onde no artigo 1. se refere expressamente que a actividade desta sociedade será desenvolvida para prestar serviços aos sócios e para a satisfação das suas necessidades e interesses, o que implica que usem os bens e serviços desenvolvidos por esta. Por outro lado, estabelece o direito de participar nas actividades da cooperativa, para que se cumpra o objecto social, o que, como é óbvio, implicará também, a utilização dos bens e serviços produzidos pela cooperativa, artigo 22.1.c). Este direito relaciona-se com o princípio da gestão democrática da cooperativa pelos membros.

\section{Deveres dos cooperadores}

Os deveres dos cooperadores encontram-se previstos no artigo $34 .^{\circ}$ do Código Cooperativo.

Do $n{ }^{\circ} 1$ constam os deveres de carácter geral, associados à noção e aos fins cooperativos, ao passo que do n. $^{\circ} 2$ resultam outros deveres de carácter pessoal e patrimonial que incidem sobre os cooperadores.

Questão que se coloca é a de saber, se os deveres dos cooperadores são apenas aqueles que vem enunciados no artigo, visto que nesta matéria o legislador não refere, como para os direitos, a expressão, nomeadamente. Assim, e embora de uma primeira análise pudéssemos concluir serem apenas estes os deveres que incidem sobre os cooperadores, encontramos no texto do Código outros deveres que vinculam o cooperador.

Tratando-se de deveres dos sócios do seu incumprimento poderá resultar a aplicação de uma sanção ou até eventualmente a exclusão do cooperador como membro da cooperativa, tudo dependendo da gravidade e da intensidade da culpa do dever violado.

Começaremos por analisar aqueles que, expressamente vêm referidos no artigo.

Na Lei de Cooperativas da Galiza, esta matéria dos deveres dos sócios, aparece tratada no artigo 24. sob a epígrafe "obrigações dos sócios".

\subsection{Respeitar as normas legais e contratuais}


O n. ${ }^{\circ}$ I do artigo $34 .^{\circ}$ estabelece que os cooperadores devem respeitar os princípios cooperativos, as leis, os estatutos da cooperativa e os regulamentos internos.

Os princípios cooperativos definem o ideal da cooperativa e preenchem a sua noção, e nessa medida vinculam todos aqueles que pertencerem a uma pessoa colectiva com as características da cooperativa.

Assim, os princípios cooperativos constantes no artigo $3 .^{\circ}$ do Código condicionam a adesão e a permanência dos cooperadores na cooperativa. Esses princípios são o da adesão voluntária e livre, o da gestão democrática pelos membros, o da participaçăo económica dos membros, o da autonomia e independência, o da educação, formação e informação, o da intercooperação e o do interesse pela comunidade.

Por outro lado, além do respeito pelos princípios cooperativos a norma impõe também o cumprimento das leis, donde ressalta pela sua importância o Código Cooperativo, e também todas as normas resultantes da legislação de cada ramo cooperativo.

Constata-se ainda ser um dever dos cooperadores o cumprimento de todas as obrigações de origem estatutária. Os estatutos, sendo a lei própria e específica de cada cooperativa, podem estabelecer outros deveres para os cooperadores, conforme o previsto na alínea a) do n. ${ }^{\circ} 2$ do artigo $15 .{ }^{\circ 9}$

Além destas obrigações, os sócios tem também de respeitar o disposto nos regulamentos internos da cooperativa.

Na Lei de Cooperativas da Galiza encontramos também no artigo 24.1. alínea b) a obrigação de cumprir as obrigações que surjam por via da lei ou dos estatutos, e bem assim aquelas que surjam por via das decisões validamente aprovadas pelos órgãos sociais. É com base nesta última parte da norma que podemos afirmar ter este direito um conteúdo mais amplo relativamente à lei portuguesa. Apesar de no Código Cooperativo não aparecer expressamente referido como dever dos cooperadores a obrigação de respeitar as deliberações dos órgãos, esta é também uma exigência dos cooperadores relativa à organização social.

19 Se os estatutos não estabelecerem outros deveres, ficam os cooperadores sujeitos aqueles que a lei estabelecer, e nos termos em que os previr. 


\subsection{Participar nas assembleias gerais ${ }^{50}$}

Da alínea a) do número 2 do artigo $34 .^{\circ}$ constata-se que os cooperadores tem o dever de tomar parte nas assembleias gerais ${ }^{51}$.

Trata-se assim, simultaneamente de um dever e de um direito, a cujo conteúdo já nos referimos quando analisamos a alínea a) do $n .{ }^{\circ} 1$ do artigo $33 .^{\circ}$ do Código Cooperativo.

Participar na assembleia geral, implica regra geral, estar presente e discutir as propostas apresentadas, como também votar os pontos constantes da ordem de trabalhos.

Na Lei de Cooperativas da Galiza, este dever dos sócios aparece previsto na alínea a) do artigo 24. onde a obrigação é mais anpla do que no Código Cooperativo Português. Com efeito aqui a obrigação estende-se à obrigação de comparência às reuniões de todos os órgãos para que tenha sido convocado, traduzindo-se este dever na manifestação de um dos princípios cooperativos, o da gestão democrática pelos membros da cooperativa.

\subsection{Aceitar o exercício de cargos sociais}

De acordo com a alínea b) do . $^{\circ} 2$ do artigo $344^{\circ}$ é um dever do cooperador aceitar e exercer os cargos sociais para que tenha sido cleito.

Como é sabido os cooperadores podem ser eleitos para a mesa da assembleia geral direcção, para o conselho fiscal, ou eventualmente para outros órgãos que os estatutos tenham criado, artigo $39 .^{\circ}$ do Código Cooperativo.

O exercício das funções nos cargos sociais mantém-se pelo período de quatro anos, se outro mais curto não for previsto nos estatutos.

$O$ exercício incorrecto das funções que lhe foram confiadas, enquanto membro do órgão respectivo para além de poder implicar perda do respectivo mandato ${ }^{52}$, poderá determinar responsabilidade civil e

\footnotetext{
${ }^{50}$ Independentemente da natureza da sessão: ordinária que obrigatoriaınente reunirá duas vezes por ano, ou extraordinária quando for convocada para além das reuniões extraordinárias, conforme o estatuído nos três números do artigo $455^{\circ}$.

${ }^{51}$ Como oportunamente já referimos participam na assembleia geral todos os cooperadores no pleno gozo dos seus direitos, n. 2 do artigo $44 .^{\circ}$ do Código Cooperativo.

${ }^{52}$ Nos termos previstos no artigo $41{ }^{\circ}$ do Código Cooperativo.
} 
criminal dos membros de alguns órgãos, nos termos dos artigos $64 .^{\circ} \mathrm{e}$ seguintes.

Admite-se, que excepcionalmente, e quando tiver motivo justificado, o cooperador possa pedir escusa para o exercício do cargo para que foi cleito.

A Lei de Cooperativas da Galiza dirige também aos seus sócios a obrigação de aceitar os cargos para que tenham sido eleitos, admitindo tal como em Portugal, que os sócios possam não assumir esses cargos quando tenham justa causa, por exemplo, por motivo de doença, idade, ou até das incompatibilidades existentes. A análise da justa causa tem de ser realizada em função de cada caso concreto, conforme o previsto no artigo 24.h).

\subsection{Participar nas actividades da cooperativa}

Na alínea c) do n. ${ }^{\circ} 2$ do artigo $34 .^{\circ}$ prevêem-se dois deveres distintos. Participar em geral nas actividades da cooperativa, no sentido de ser um membro participativo e interessado na vida cooperativa.

Além deste dever, o cooperador obriga-se a prestar o serviço ou trabalho que the competir em função do objecto ou do ramo da cooperativa.

Também encontramos na Lei de Cooperativas da Galiza como dever dos sócios a participação nas actividades da cooperativa que traduzam o desenvolvimento do objecto social. Neste regime destaca-se a obrigação de participar nas actividades de formação que se traduz também num dever do sócio, conforme o previsto na alínea g) do artigo 24. que desenvolve lambém um dos princípios cooperativos.

\subsection{Efectuar os pagamentos exigiveis}

O cumprimento deste dever aparece tratado na alínea d), cabe ao sócio efectuar os pagamentos exigíveis.

Esta obrigação pode ter fonte diversa. Pode surgir nos termos do Código, nos termos dos estalutos da cooperativa, ou nos moldes fixados em regulamento interno.

Trata-se de um dever de cariz patrimonial, cujo cumprimento pode até condicionar a aquisição da qualidade de cooperador, como aconte- 
ce com a obrigação de realizar o capital subscrito, e de pagar a jóia nos termos fixados nos estatutos, temas aos quais já nos referimos ao longo deste trabalho. Além de realizar a entrada o cooperador pode ter também de pagar o valor da jóia. Além destes pagamentos, pode o cooperador ter de participar nas perdas da cooperativa, efectuando os pagamentos devidos a este lítulo.

De notar que o não cumprimento dos pagamentos a que o membro está obrigado, pode determinar, se assim estiver previsto nos estatutos, a exclusão como membro da cooperativa, seguindo nesse caso o processo, formalidades especiais e menos exigentes relativamente à exclusão cujo fundamento seja diferente deste que acabamos de referir.

O cumprimento das obrigações económicas por parte dos sócios é também um aspecto relevante do regime na Lei de Cooperativas da Galiza. Esta obrigação consta da alínea 1) do artigo 24.

Daí resulta o dever de contribuir para o capital social nas condições previstas noos estatutos da cooperativa. No conteúdo deste dever cabem as contribuições obrigatórias, como por exemplo a obrigação de realizar a entrada, as contribuiçōes voluntárias, o pagamento das quotas de ingresso (jóias) ou outras quotas periódicas especificamente previstas, conforme o previsto nos artigos 58 . e seguintes da Lei de Cooperativas da Galiza. Nos vários números do artigo 59. regulam-se os efcitos do incumprimento desta obrigação que em últimá análise pode, como no direito Português, ser causa de expulsão do sócio.

\subsection{Outros deveres previstos no Código Cooperativo}

\subsubsection{Dever de quinhoar nas perdas}

Um outro dever que incide sobre os cooperadores é o que os obriga a quinhoar nas perdas dá cooperativa.

Não é considerado um dos principais deveres dos cooperadores, e por isso não vem referido no artigo $34 .^{\circ} .53$

\footnotetext{
${ }^{53} \mathrm{O}$ que nos permite conchuir que o capital e os aspectos decorrentes da participação económica dos membros é menos relevante do que a vertente pessoal e os deveres de natureza pessoal.
} 
Além do mais, não é este um dever que decorre sempre para os cooperadores, pois existirá apenas quando a assembleia geral o deliberar. ${ }^{54}$

Este dever de participar nas perdas da cooperativa vem referido no n. 4 do artigo $69 .^{\circ}$ do Código Cooperativo, quando a propósito da matéria da reserva legal, se estabelece a possibilidade de a assembleia geral deliberar a responsabilização dos cooperadores pelo valor das perdas que a reserva legal não cobrir.

Neste caso, o critério a seguir é o da responsabilização proporcional dos cooperadores, em função das operações realizadas com a cooperativa.

Embora a obrigação de participar nas perdas da cooperativa não resulte dos deveres expressamente previstos no arligo 24. da Lei de Cooperativas da Galiza, tal obrigação impõe-se por via do estatuído no regime económico, em especial no artigo 69.2. c), tal como na lei portuguesa essa responsabilidade será distribuída em propocção das actividades, operações ou serviços realizados entre o sócio e cooperativa.

\subsubsection{Dever de lealdade}

Decorre da filosofia da cooperativa e do respeito pelos princípios cooperativos a honestidade, probidade e dedicação à causa cooperativa por parte dos cooperadores.

Muito embora, o Código Cooperativo não se refira expressamente a este dever, a lealdade que se impõe aos cooperadores pode revestir vários aspectos, como a ideia de não concorrência ${ }^{55}$ com a actividade da cooperativa e como o cumprimento do dever de sigilo.

Ao contrário do Código Cooperativo, a Lei de Cooperativas da Galiza refere-se expressamente ao dever de lealdade dos sócios em relação à cooperativa. Com efeito, em duas das alíneas do artigo 24. se podem encontrar obrigações dos sócios que são manifestações deste dever. Na alínea d) é um dever do sócio não concorrer com a coopera-

\footnotetext{
${ }^{54}$ Nesta característica podemos encontrar outro aspecto da distinçăo entre as cooperativas e a sociedade comercial, pois nestas é sempre um dever dos sócios a participação nas perdas geradas pela sociedade.

${ }^{55}$ A proibição de concorrência com a cooperativa também se admite poder ser imposta pelos estatutos, nos termos do artigo 14.1.8.
} 
tiva. A proibição de desenvolver actividades concorrenciais já não se impõe, se o sócio for, para tal, expressamente autorizado.

Na alínea e) do artigo referido impõe-se ao sócio o dever de sigilo sobre os assuntos e informações da cooperativa, cuja revelação possa prejudicar os seus interesses.

\section{Regime disciplinar}

A posição de cooperador, é uma posição de responsabilidade, sendo uma consequência da adesão livre e voluntária. Com efeito, só podem ser membros, aqueles que, quiserem aderir à cooperativa para utilizar os seus serviços e estiverem dispostos a assumir as responsabilidades inerentes aos membros, que já tivemos oportunidade de analisar.

Uma parte da responsabilidade que o membro assume perante a cooperativa tem a ver com a sua submissão ao exercício do poder disciplinar.

O exercício deste poder disciplinar traduz-se na possibilidade de a cooperativa através dos órgãos competentes punir determinadas condutas dos membros, aplicando-lhe sanções.

Admite o legislador no $n .^{\circ} 2$ do artigo $15 .^{\circ}$ do Código Cooperativo que esta poderá ser uma das matérias tratadas nos estatutos de cada cooperativa. Desde logo na alínea a) admite-se que os estatutos possam incluir normas sobre as condições de admissão, suspensão, exclusão e demissão dos membros, podendo ler-se na alínea b) que os estatutos podem fixar as sanções e as medidas cautelares, e bem assim as condições gerais da sua aplicação ${ }^{56}$.

Como já referimos a propósito de outras matérias, se os estatutos, tratarem destas matérias serão essas as normas a aplicar, na falta de disposição estatutária sobre o regime disciplinar aplicar-se-ão as normas do Código Cooperativo, que têm aqui natureza supletiva ${ }^{57}$.

Quando falamos de regime disciplinar dos cooperadores podemos estar a valorizar vários aspectos. Assim, preenchem este regime, os

\footnotetext{
${ }^{56}$ Apesar de neste artigo se fazer referência a sanções e a medida cautelares, no código apenas se encontram elencadas as sanções, muito embora no artigo 38. a referência à suspensão temporária de direitos possá ser vista como uma medida cautclar cuja aplicação permite evitar consequências mais gravosas para a cooperativa.

${ }^{57}$ Conforme o previsto no n. ${ }^{\circ} 3 \mathrm{do}$ artigo $15 .^{\circ}$ do Código Cooperativo.
} 
comportamentos dos membros que dão lugar ao exercício do poder disciplinar, o próprio processo para aplicar as sanções, análise do elenco das sanções a aplicar aos cooperadores, os prazos do exercício da acção disciplinar e órgãos competentes para o exercício do poder disciplinar.

Do regime disciplinar que encontramos no código, concluímos que os aspectos em que se centra esta disciplina são as sanções e o processo para as aplicar.

Os artigos 25. e 26. tratam do regime disciplinar dos sócios na Lei de Cooperativas da Galiza. Remete-se nesta matéria para os estatutos de cada cooperativa. É aqui que se tipificarão os comportamentos que irão conduzir à aplicação das sanções, comportamentos esses que serão graduados em faltas leves ${ }^{58}$, graves e muito graves, bem como do procedimento para aplicar as sanções e respectivo sistema de recursos, artigo 25.1. da Lei de Cooperativas da Galiza. A reforçar esta ideia o artigo 14.1.10 estabelece ser esta uma das matérias que faz parte do conteúdo mínimo dos estatutos de cada cooperativa.

\subsection{Comportamentos que conduzem à aplicação de sanções}

No que concerne aos factos que dão lugar à aplicação das sanções disciplinares são escassas as referências do legislador cooperativo.

Apenas se referiu ao tipo de comportamentos quando estiver em causa a aplicação da pena mais grave, que é a da exclusão do membro.

Sempre se poderá dizer que os factos que conduzirão à aplicação de sanções hão-de consistir em violações mais ou menos graves, culposas ou não, das leis cooperativas, dos estatutos ou dos regulamentos internos.

Sobre esta matéria refere o legislador que o facto que conduzir à aplicação da sanção de exclusão consistirá numa violação grave e culposa do Código Cooperativo, da legislação complementar aplicável aos ramos do sector cooperativo, dos estatutos ou dos regulamentos internos.

A opção do legislador que se traduz numa cláusula geral com o conteúdo referido, consiste na delimitação das violaçốes, que sendo graves e culposas podem conduzir à aplicação da medida mais grave, a exclusão.

\footnotetext{
${ }^{58}$ Quanto a estas também se admile poderem vir a ser previstas no regulamento interno ou por deliberação da assembleia geral, artigo 25.1 .
} 
Na Lei de Cooperativas da Galiza não se fixam, como referimos no ponto anterior, nem os comportamentos, nem as sanções que se lhes aplicarão, remetendo-se para os estatutos das cooperativas o tratamento desta matéria.

\section{2. Órgãos competentes para o exercício do poder disciplinar}

\subsubsection{Competência da direç̧ão}

Cabe à direcção enquanto órgão de administração e representação da cooperativa o exercício da acção disciplinar, conforme resulta das competências referidas na alínea d) do artigo $56 .^{\circ}$ do Código Cooperativo. E por isso, podemos afirmar que, regra geral, compete à direç̧ão decidir sobre a aplicação de sanções e conduzir o respectivo processo.

É o órgão com competência disciplinar que avalia a gravidade do comportamento, o grau de culpa que o mesmo revela, e, nessa medida ajuíza com a necessária proporcionalidade, a aplicação das sanções. Da decisão da direcção em matéria disciplinar cabe recurso para a assembleia geral.

Na Lei de Cooperativas da Galiza a competência para aplicar as sançôes cabe ao órgão de administração, artigos 25.3.a) e 26.1..

\subsubsection{Competência da assembleia geral}

Constatamos que à assembleia geral é atribuída em matéria disciplinar dois tipos de competência: a deliberação sobre a aplicação das sanções mais graves, e o funcionamento como instância de recurso das decisões da direç̧ão sobre aplicação das restantes sanções: repreensão registada, multa e a suspensão temporária de direitos ${ }^{5 \%}$.

Quando a sanção a aplicar ao membro da cooperativa, for a da exclusão e a da perda de mandato dos membros dos órgãos sociais é competente para a sua aplicação a assembleia geral, conforme a alínea 1) do artigo 49..$^{\circ}$ do Código da Cooperativo.

A assembleia geral tem ainda competência como instância de recurso quanto às sanções aplicadas pela direcção. Da sanção de exclu-

\footnotetext{
${ }^{5 \%}$ Esta conclusăo retira-se também do n." 3 do artigo 38. do Código Cooperativo.
} 
são aplicada pela assembleia geral cabe recurso para os tribunais nos termos do n. ${ }^{\circ} 7$ do artigo $38 .^{\circ}$.

Esta ideia de que a assembleia geral pode funcionar como instância de recurso, também consta da Lei de Cooperativas da Galiza. Podemos encontrar esta competência atribuída à assembleia geral, no artigo 25. 3. c) no primeiro parágrafo. Este artigo trata do procedimento disciplinar a desenvolver quando se pretenda aplicar uma das sanções que não a expulsão, e neste caso atribui-se ao comité de recursos ${ }^{6}$ a apreciação do recurso. Quando não exista este órgão, então defere-se à assembleia geral competência para apreciar o recurso interposto pelo sócio".

Do artigo 26. 2. decorre que, se a pena aplicada ao sócio for a de expulsão, então a competência para apreciar o recurso cabe à assembleia geral, admitindo-se que possa ter delegado por via estatutária essa competência ao comité de recursos, caso em que será este o órgão com competência para o conhecer. No 2..$^{\circ}$ parágrafo deste artigo também se prevê a impugnação judicial da deliberação de expulsão.

\subsection{Sanções previstas no Código Cooperativo ${ }^{62}$}

Encontra-se no Código uma distinção das sanções a aplicar aos cooperadores de acordo com a gravidade das suas consequências, nomeadamente, a que determina perda da qualidade de cooperador, e as que não têm este efeito, facto que determinou um tratamento separado dos dois tipos de sanções. Assim, no artigo $37 .^{\circ}$ trata-se apenas da exclusão do cooperador, e no artigo $38 .^{\circ}$ das outras sanções, que, sem prejuízo do disposto nos estatutos ou nos regulamentos internos são: a repreensão registada, a multa, a suspensão temporária de direitos, e a perda de mandato.

\footnotetext{
${ }^{60}$ Quando o recurso corra perante o comité de recursos também se deverá ouvir o interessado, que também se poderá defender por escrito, nos termos do 25.3. c) $2 .^{\circ}$ parágrafo.

${ }^{\text {"N }}$ Neste caso, o recurso deverá ser incluído como primeiro assunto da ordem do dia na primeira assembleia que se realize, e será decidido por votação secreta. Deverá o sócio interessado ser ouvido e defender-se por escrito, como o previsto no artigo 25.3.c) 1 . parágrafo.

${ }^{62} \mathrm{Na}$ Lei de Cooperativas da Galiza, visto serem os estatutos de cada cooperativa que inão tipificar as sanções a aplicar aos seus sócios, apenas se refere no artigo 25.1. que as san çôes poderão ser económicas, de suspensão de direitos sociais ou a pena de expulsão.
} 


\subsubsection{Repreensão registada}

Esta sanção vem prevista na alínea a) do número 1 do artigo $38 .^{\circ}$, e apresenta-se no elenco das sanções previstas no código a menos grave.

Traduz-se na advertência que a direcção dirige ao cooperador que violou algum dos deveres ou princípios cooperativos que as normas the dirigem.

A advertência ficará registada no processo individual do cooperador a que for aplicada, e poderá servir como factor a considerar na aplicação de futuras sanções ao cooperador em questão.

Do exposto conclui-se a necessidade de as cooperativas disporem de um registo disciplinar dos cooperadores.

Mesmo sendo a sanção mais leve, a sua aplicação pela direcção da cooperativa não dispensa a realização do processo, que funciona, como é óbvio como uma garantia de defesa do cooperador, nos termos do n. 2 do artigo $38 .^{\circ}$ que remete no que ao processo respeita para o regime fixado no artigo $37 .^{\circ}$ do Código Cooperativo.

\subsubsection{Multa}

É a segunda sanção que vem referida no n. ${ }^{\circ} 1$ do artigo $38 .^{\circ}$, consta da alínea b). Sendo o elenco de sanções gradativo, a aplicação desta sanção pressupõe que o comportamento do cooperador em questão, não se mostre reparado com a aplicação da sanção referida no ponto anterior, exige portanto uma maior gravidade dos factos praticados.

Caracteriza-se como uma sanção de carácter pecuniário, cujo destino, muito embora a lei não o refïra serão os cofres da cooperativa.

$\mathrm{Na}$ Lei de Cooperativas da Galiza admite-se que as sançōes possam ser económicas, e nessa medida, uma das sanções que os estatutos poderão prever será a pena de multa, conforme o artigo 25.1 parte final.

\subsubsection{Suspensão temporária de direitos}

A suspensão temporária dos direitos do cooperador é outra das sanções que exemplificativamente se referem no n." I do artigo $38 .^{\circ}$ do Código Cooperativo. Esta sanção vem referida na alínea c). O carácter sancionatório advém da limitação resultante para o estatuto jurídico do 
cooperador, que enquanto durar a sanção está limitado no exercício de todos ou parte dos seus direitos.

Do conteúdo da medida resultam várias notas, a primeira é da transitoriedade da situação, e por isso se acentua o seu carácter limitado. A segunda resulta de em concreto, o cooperador estar limitado no exercício de mais ou menos dos seus direitos ${ }^{63}$, o que será analisado e deliberado pela direcção atendendo à gravidade e à culpa do comportamento do membro.

A esta medida tem sido apontada uma dupla funcionalidade, enquanto medida repressiva quando se destina a sancionar o cooperador, e medida preventiva enquanto instrumento destinado a assegurar o normal andamento da acção disciplinar: ${ }^{(4)}$

Também se admite que as sanções a aplicar aos sócios nas cooperativas da (ializa possam ter esta vertente de suspensão de direitos, no entanto, serão os estatutos que irão prever em que consiste a suspensão e os efeitos que determina. O ponto 4. do artigo 25. estabelece que esta apenas deverá ser aplicada quando estejam em causa o incumprimento das obrigações económicas ou a falta de participação nas actividades da cooperativa.

De notar ainda a preocupação manifestada pelo legislador quando no 2. parágrafo estabelece que a suspensão cessará logo que cesse a situação que a motivou. E por outro lado, a sua aplicação nunca afectará o direito à informação, o direito a participar na assembleia geral, nem o direito a receber o juros devidos pelas entradas realizadas, nem as actualizações das mesmas.

\subsubsection{Perda de mandato}

Esta sanção que vem referida na alínea d) do n. 1 do artigo $38 .^{\circ} \mathrm{e}$ é, das referidas no artigo, a mais grave que pode ser aplicada ao cooperador.

Esta sanção dirige-se aos membros dos órgãos da cooperativa, e vem tratada no artigo $41 .^{\circ}$ do Código Cooperativo.

\footnotetext{
${ }^{{ }^{13}}$ Há direitos que não podem ser uspensos, como sejam o direito à demissão e o direito do recurso da sanção.

${ }^{1+}$ Esta scrá uma das medidas cautelares a que se refere a alínea b) do 11.02 do artigo $15 .^{\circ}$ do Código Cooperativo, e que a par de outras podem constar dos estatutos.
} 
De acordo com esta norma são causa da perda de mandato dos membros dos órgãos: a declaração de falência dolosa e a condenação por crimes contra o sector público ou contra o sector cooperativo e social, designadamente pela apropriação de bens do sector cooperativo e social e por administração danosa em unidade conómica nele integrada.

A perda de mandato pode acontecer por destituição da assembleia geral, conforme o previsto na alínea a) do artigo $49 .^{\circ}$ do Código Cooperativo.

É assim uma das medidas cuja aplicação cabe à assembleia geral, nos termos da alínea 1) do artigo referido em conformidade com o n. 3 do artigo $38 .^{\circ}$.

\subsubsection{Exclusão}

Esta sanção é a mais grave que a cooperativa pode aplicar aos seus membros, e isto porque, implica a perda da qualidade cooperador ${ }^{6.5}$. Exactamente por esse facto, só deve ser aplicada quando nenhuma das outras sanções seja suficiente para garantir a punição pelo comportamento do membro ${ }^{66}$.

Por outro lado, atenta a gravidade desta sanção, o legislador tratoua em norma separada das outras sanções, utilizando para o efeito os nove números do artigo $37 .^{\circ}$ do Código.

Foi em relação a esta sanção de exclusão que o legislador estabeleceu os requisitos gerais da sua aplicação que são a gravidade da conduta c a culpa do agente ${ }^{67}$ na violação do Código, da legislação complementar, dos estatutos ou dos regulamentos internos. Só se se encontrarem preenchidos estes requisitos, pode a assembleia deliberar, no caso concreto, a exclusão do membro ${ }^{6.8}$.

\footnotetext{
"Sob o ponto de vista da cooperativa esta sanção também não é desejável pois determina a diminuição do seu capital.

${ }^{(6)}$ A título de exemplo nas cooperativas agrícolas será fundamento para a exclusão dos cooperadores a exploração ou negociação de forma concorrencial com a cooperaliva, a transferência para outros dos benefícios que só aos cooperadores é lícito receber, a não participação na subscrição do capital nos termos previstos nos estatutos, conforme o artigo 9. do DL $335 / 99$ de 20 de Agosto.

${ }^{67}$ Podendo a culpa consistir no dolo ou na negligência da condula do cooperador.

${ }^{6} \mathrm{O}$ artigo 51.0 não prevê sobre esta matéria a necessidarde de una maioria qualificada, pelo que a deliberação será tomada por maioria dos votos emitidos.
} 
É no âmbito da aplicação desta pena que o legislador se refere às formalidades necessárias para a aplicar, o que denota a gravidade da sanção e em especial das suas consequências ${ }^{69}$.

Aquele que vier a ser excluído da cooperativa tem direito que the seja restituído o montante dos títulos que subscreveu, pelo seu valor nominal, bem como os juros a que tiver direito relativamente ao último exercício, e ainda a sua parte nos excedentes e nas reservas. Admite-se ainda que possa incorrer em responsabilidade pelo cumprimento das suas obrigações até ao momento em que a aplicação da sanção se efectivar, de acordo com o disposto no n. $^{\circ} 9$ do artigo $37 . .^{\circ}$.

Também na Lei de Cooperativas da Galiza se prevê a possibilidade de ser aplicada a pena de expulsão ao sócio.

Tal como no Código Cooperativo, vem tratada em norma distinta das demais sanções. Só se admite a aplicação desta pena aos sócios nos casos em que tenham cometido uma violação muito grave prevista nos estatutos e, em todo o caso sempre com audiência prévia do interessado, conforme o artigo 26. 1. da Lei de Cooperativas da Galiza ${ }^{70}$.

Admite-se também, a possibilidade de a exputsão ser determinada por falta de cumprimento das obrigações económicas, caso em que o processo disciplinar sofre algumas especialidades, as constantes do segundo parágrafo do ponto 1. do artigo 26. Neste caso o sócio tem também o direito que the sejam devolvidos os valores com que tiver contribuído para a cooperativa, conforme decorre do artigo 22.1.f).

Tambérn se admite a possibilidade de o sócio poder recorrer da aplicação desta sanção. Em princípio o recurso será apresentado à assembleia geral, excepto se esta tiver delegado estatutariamente essa competência no comité de recursos, conforme o artigo 26.2.

Além deste recurso também se admite que a decisão de expulsão possa ser impugnada judicialmente, nos termos do 2..$^{\circ}$ parágrafo do artigo anterior.

Referiremos no ponto seguinte deste trabalho o processo para aplicação da acção disciplinar.

\footnotetext{
(6) Muito embora no n." 2 do artigo 38. quando se refere às outras sançôes imponha o recurso a este inesmo processo, como condição da sua aplicação aos cooperadores.

"São os estatutos que terão de estabelecer quais os comportamentos do sócio a que atribui a natureza de faltas muito graves, pois só a esses se poderá aplicar esta pena.
} 


\subsection{Processo para aplicação de sanções}

Além dos requisitos substanciais para aplicação das sanções importa também cumprir os requisitos formais a que se refere o artigo $37 .^{\circ}$ do Código Cooperativo.

Como já referimos apesar do processo vir tratado no artigo que se refere à exclusão, aplica-se a todas as sanções, por força do preceituado no n. 2 do artigo $38 .^{\circ}$ do Código Cooperativo.

Trata-se de um processo escrito ${ }^{71}$ composto por várias fases e que vêm referidas no n. 3 do artigo $37 .^{\circ}$, que apesar de não als designar como tal, nos permitem identificar quatro fases distintas. A fase da acusação, da defesa, da produção da prova e a da proposta de decisão.

\section{a) Fase da acusação}

Nesta fase, com que se inicia o processo disciplinar, têm de ser levados ao conhecimento do cooperador vários aspectos: a indicação das infracçōes e a sua qualificação, bem como as provas en que assenta a imputação desses factos ao cooperador:

Determina a nulidade do processo disciplinar a insuficiente individualização das infracções imputadas ao cooperador - arguido, bem como a falta da referência aos preceitos violados, conforme as alíneas b) e c) do $1 .^{\circ} 5$ do artigo $37 .^{\circ}$ do Código.

\section{b) Fase da defesa}

A defesa do arguido implica que o mesmo seja ouvido, e que eventualmente sejam cumpridas algumas diligências probatórias que o mesmo solicite.

O não cumprimento das garantias de defesa do arguido pode comprometer a aplicação da sanção, considerando a alínea a) do n. 5 uma nulidade insuprível a falta de audiência do arguido.

\section{c) Fase da instrução}

Para que haja uma defesa eficaz do arguido, e para que o processo de aplicação das sanções, seja justo, é necessário que, quer quem acu-

\footnotetext{
${ }^{7}$ Pois só assim se assegum todas as garantias de defesa.
} 
sa, quer quem é acusado possa socorrer-se da produção de prova para que venha a descobrit-se a verdade dos factos.

A omissão de quaisquer diligências ${ }^{72}$ essenciais para a descoberta da verdade afecta o processo com uma nulidade insanável, conforme a alínea d) do n. 5 do artigo $37 .^{\circ}$ do Código Cooperativo.

\section{d) Fase da decisão}

O processo disciplinar conclui-se com a decisão que fixa, de acordo com os factos de que é acusado, a clefesa efectuada, e as provas produzidas a sanção que vai ser aplicada ao arguido.

Refere o n. 7 do artigo $37 .^{\circ}$ que a decisão será fundamentada, e notificada por escrito ao arguido.

De notar que quando a sanção a aplicar for a exclusão ${ }^{13}$ o processo sofre algumas especialidades, como aquela que consta deste n. ${ }^{\circ}$ do artigo $37 .^{\circ}$, e que estabelece a necessidade de notificar o arguido com pelo menos sete dias de antecedência em relação à data em que esse realizará a assembleia geral que decidirá excluir o sócio.

A exclusão deve ser deliberada no prazo máximo de um ano a partir da dalta em que algum dos membros da direção tomou conhecimento do facto que a permite. Do exposto pode concluir-se que a decisão de instaurar o processo cabe à direcção, sendo a decisão de aplicar a pena da competência da assembleia gelal.

Quando a sanção a aplicar pela assembleia geral for a cxclusão, desta deliberação da assembleia geral cabe recurso para os tribunais.

Na Lei de Cooperativas da Galiza, também se remete nesta matéria para o disposto nos estatutos da cooperativa. Refere o artigo 25.3. que serão os estatutos que estabelecerão o processo para aplical o exercício do poder disciplinar, bem como o sistema de recursos aplicável no seu caso específico.

\footnotetext{
${ }^{72}$ Cabem aqui todo o tipo de diligências: a audição de testemunhas, a análise de documentos, a audição de gravaçōes ou a visualização de filmagens, por exemplo.

${ }^{73}$ De salientar que, se a exclusão for fundamentada no atraso nos pagamentos a que o sócio está obrigado, não é necessária a realização do processo nos termos que expusemos, basta apenas, o envio de carta registada para o domicílio do infractor con o aviso prévio do prazo em que poderá regularizar a situação, de acordo com o previsto no n. ${ }^{\circ} 4$ do artigo $37 .^{\circ}$ do Código Cooperativo.
} 
O que a lei faz nas várias alíneas e parágrafos do ponto 3 é estabelecer as normas essenciais a que sujeita a aplicação de sanções aos sócios de todas as cooperativas.

Assim, a regra base em que assenta o exercício desta acção disciplinar, é a da audiência do interessado e a possibilidade de se defender por escrito, apresentando para o efeito alegações, segundo o previsto na alínea b) do ponto 3 .

Na alínea c) e seus parágrafos do (ue se trata é de fixar as regras essenciais em matéria de recursos. A regra geral é a de que o recurso deve ser apresentado no prazo de 30 dias desde da data notificação ao sócio, devendo como já referimos ser apresentado perante o comité de recursos, se existir, ou perante a assembleia geral na sua falla.

O recurso apresentado ao comité de recursos só deverá ser decidido depois de ouvido o sócio interessado. Esta deliberação do órgão que apreciou o recurso pode ser impugnada judicialmente no prazo de dois meses a contar da sua notificação.

\subsection{Prazos para aplicação de sanções}

O prazo a que o legislador se refere diz respeito à aplicação da sanção de exclusão. Assim, prevê o n. 7 do artigo $37 .^{\circ}$ que a exclusão deve ser deliberada no prazo máximo de um ano a partir da data em que algum dos membros da direcção o conheceu.

No entanto, como o n. 2 do artigo $38^{\circ}$ manda aplicar aquele processo quando estiverem em causa as outras sanções, parece poder entender-se que o prazo para aplicação de sanções é o mesmo em todos os casos.

No que respeita à Lei de Cooperativas da Galiza, também se prevêem prazos para o exercício da acção disciplinar. Assim, estabelece-se que as infracções dos sócios prescrevem no prazo de um mês se forem leves, no prazo de dois meses se forem graves, e se forem muito graves decorridos três meses desde do momento em que órgão de administração teve conhecimento. De todo o modo, decorridos 12 meses desde da data em que a infraçãa foi cometida, independentemente do órgão dela ter tido conhecimento ou não, considera-se a falta prescrita, assim o estabelece o artigo 25.2. da Lei de Cooperativas da Galiza. 


\section{Perda da qualidade de cooperador}

Ao longo da nossa análise foi possível concluir que a perda da qualidade de cooperador pode acontecer por várias formas, assim perde a qualidade de cooperador aquele que apresenta a sua demissão, e por isso podemos considerar esta perda da qualidade de membro como voluntária, porquanto resulta da manifestação da vontade do cooperador, aplicando-se aqui o artigo $36^{\circ}$ do Código Cooperativo.

Como a seu tempo notámos este é um direito que pode ser exercido por todos os cooperadores, sem necessidade de qualquer fundamentação ou justificação para o facto.

Pode o cooperador perder essa qualidade através da exclusão, sendo aqui uma perda involuntária, no sentido de não ser determinada por vontade do membro, mas antes, exprime a vontade da cooperativa, nos termos previstos e já por nós analisados no artigo $37 .^{\circ}$ do Código Cooperativo.

Em anbos os casos, como referimos, o cooperador tem direito a receber o capital realizado, os juros e a quota-parte dos excedentes que naquele exercício lhe coubessem.

Pode o cooperador perder essa qualidade, nas cooperativas de primeiro grau, e tratando-se de uma pessoa física pela ocorrência da morte.

No caso da morte do cooperador, esse facto determinará, na maior parte dos casos a perda da qualidade de cooperador. Com efeito a admissão daquela pessoa como membro da cooperativa, implica que o mesmo tenha, determinadas características, sem as quais não poderia ser cooperador.

Por outro lado, o facto de o cooperador pedir a admissão à cooperativa, significa que cabe esta a última palavra na atribuição da qualidade de cooperador, em função da análise das suas características pessoais e do cumprimento de outros requisitos de que depende como vimos, a aquisição da qualidade de cooperador.

Não sendo a cooperativa uma pessoa colectiva em que o elemento patrimonial se sobrepõe ao elemento pessoal, ${ }^{74}$ entendemos que para

${ }^{7} \mathrm{O}$ Código das Sociedades Comerciais prevê vários tipos de sociedades, é costume, considerando a maior ou menor valorização que se atribui ao elemento pessoal ou ao elemento patrimonial classificá-las em sociedades de pessoas ou de capitais. Se aplicássemos esta classificação no âmbito destas pessoas colectivas especiais que estudamos, iríamos classificá-las como "sociedades de pessoas". 
proteger os demais membros a morte do cooperador não transmite essa qualidade aos seus herdeiros. Muito embora, se admitam os direitos dos seus sucessores no que concerne aos direitos patrimoniais do cooperador falecido, que serão exercidos pela aplicação das normas previstas sobre esta matéria no Código das Sociedades Comerciais, c de acordo com as normas do direito sucessório constantes do Código Civil.

Na Lei de Cooperativas da Galiza a perda da qualidade de sócio coincide em larga medida com aquilo que encontramos no Código Cooperativo. Assim, o sócio pode perder essa qualidade por sua vontade demitindo-se da sociedade, respeitando as formalidades necessárias, nomeadamente avisando por escrito o órgão de administração ${ }^{75}$. Esta possibilidade de sair da sociedade, sem justificar ou alegar o motivo da sua saída é um direito dos sócios que faz parte do próprio conceito de sociedade, como oportunamente referimos.

Além deste caso, em que o sócio pode sair da cooperativa por sua vontade, pode também abandoná-la quando se verifique alguma causa que o fundamente ${ }^{76}$. Neste caso existe um direito de separaçăo do sócio em relação à sociedade, tratando-se de outra forma de sair da sociedade. São fundamentos da saída do sócio, neste caso, o desacordo manifestado através do voto em sentido diverso, com as deliberações sociais que impliquem a assunção de obrigações que o onerem gravemente, conforme a alínea a) do artigo 20.3., ou outras causas previstas nos estatutos, conforme a alínea b) do mesmo artigo. Neste caso deverá o sócio cumprir as formalidades e os prazos com vista à sua saída".

Outra causa da perda da qualidade de sócio que a Lei de Cooperativas da Galiza estabelece é a saída obrigatória por perda dos requisitos impostos pela lei ou pelos estatutos para se ser sócio ${ }^{78}$, conforme o previsto no ponto 4 . do artigo 20 . Trata-se de uma saída imposta, mas que

\footnotetext{
${ }^{75}$ Na Lei de Cooperativas da Galiza chama-se a esta forma do sócio sair da sociedade "baja voluntaria", conforme o artigo 1.1 .

${ }^{76}$ Neste caso trata-se também de uma "baja voluntária" mas com justa causa, artigo 20.3 da Lei de Cooperativas da Galiza.

${ }^{n}$ A figura não existe no Código Cooperativo Português. Existe no direito societário em relação a algumas categorias de sociedades: as classificadas como socicdades de pessoas, e chama-se exoneração. Sendo o Código das Sociedades aplicável subsidiariamente às cooperativas, admite-se que com algumas adaptações possa aplicar-se às cooperativas.

${ }^{73}$ Neste caso designam esta saída como "baja obligatória".
} 
não pode ser considerada como um sanção pois não assenta num facto praticado pelo sócio que poderá conduzir à aplicação de uma pena de expulsão, que analisamos no ponto anterior deste trabalho. Sobre esta forma de perder a qualidade de cooperador não fala o Código Cooperativo.

\section{CONCLUSÕES}

1. A qualidade de membro da cooperativa é atribuída a pessoas ou entidades diferentes consoante se trate de cooperativas de primeiro ou a segundo grau.

2. A aquisição da qualidade de membro nas cooperativas de primeiro grau pode ser atribuída a pessoas singulares ou colectivas que preencham os requisitos legais e estatutários e de acordo com o Código Cooperativo que tenham personalidade jurídica. Este último requisito não se impõe na Lei de Cooperativas da Galiza que admite que as comunidades de bens possam ser membros da cooperativa.

3. Um dos requisitos de que depende a qualidade de membro, e em que assenta a figura da cooperativa, é o respeito pelos princípios cooperativos, que condicionam não só a adesão, como também a manutenção do vínculo à cooperativa.

4. Os membros das cooperativas para adquirirem tal qualidade deverão satisfazer os requisitos de participação económica, em especial, a obrigação de realizar as entradas, as jóias, e eventualmente outras obrigações fixadas pelos estatutos.

5. Além da verificação de tais requisitos, só adquirirá a qualidade de membro da cooperativa aquele que pretendendo entrar, satisfaça as exigências referidas, e solicite a sua admissão à direcção.

6. Sendo a regra a da admissão dos membros, em conformidade com o "princípio da porta aberta", a recusa da entrada na cooperativa admite recurso interno para outro órgão da cooperativa, no caso Português para a assembleia geral, no caso das cooperativas da Galiza para o comité de recursos ou na sua falta para a assembleia geral.

7. Prevê-se a possibilidade dos estatutos, enquanto regulamentação específica da cooperativa, estabelecerem outros requisitos além dos enumerados na lei geral.

8. Por outro lado existem requisitos especiais de admissibilidade dos membros às cooperativas em função do ramo de cooperativa a que 
pretendem aderir, sendo também a sua verificação um requisito que condiciona a admissibilidade de novos membros à cooperativa.

9. Em matéria de direitos concluímos que a enumeração feita na lei não é taxativa, pois podem resultar outros direitos dos estatutos da cooperativa.

10. Constatamos que a lei defere aos membros das cooperativas vários direitos, uns de índole pessoal, outros de índole patrimonial.

11. No direito cooperativo português sobressai a tutela dos direitos de carácter pessoal, porquanto são estes que garantem a gestão e a participação democrática dos seus membros, princípio cooperativo basilar, que reflecte a tendência nacional de não considerar a cooperativa como uma sociedade.

12. De entre os direitos pessoais consagrados, destaca-se um deles por aparecer ligado à noção de cooperativa, e ao princípio da adesão voluntária e livre dos membros, e que se exprime no direito atribuído aos membros de abandonarem livremente a cooperativa.

13. Este direito, que se apresenta mais desenvolvido na Lei de Cooperativas da Galiza, permite que o sócio mesmo sem justa causa possa abandonar a cooperativa, cumprindo apenas um prazo de aviso prévio, no Código Cooperativo Português chama-se o direito à demissão.

14. Para poderem exercer efectivamente os scus direitos, ambas as leis atribuem aos membros das cooperativas, o direito à informação que se revela essencial. Através deste direito podem os membros solicitar, en vários momentos da vida da cooperativa informações, em especial as que se relacionam com o objecto social desenvolvido pela cooperativa, pelo que, apresenta uma natureza instrumental face aos demais.

15. No que concerne aos direitos de natureza pessoal, podemos ainda destacar o direito a participar e votar nas assembleias gerais, o direito de a convocar, e o direito de ser eleito e de eleger os órgãos sociais.

16. Quanto aos direitos económicos destacam-se o direito a receber uma remuneração pelo capital investido, o direito aos lucros e o direito de utilizar os bens e serviços da cooperativa.

17. Em matéria de deveres, impõe-se o respeito pelos que tenham natureza legal e estatutária. Alguns dos deveres tem exacta correspondência nos direitos dos membros, como o dever de participar nas assembleias gerais e o dever de aceitar os cargos para que tenha sido eleito. 
18. A lei impõe aos membros da cooperativa a obrigação de participar nas actividades da cooperativa, nos termos previstos nos estatutos.

19. Sob a perspectiva económica, a lei dirige a todos os membros das cooperativas a obrigação de realizar os pagamentos exigíveis, em especial a obrigação de realizar as entradas, jóias, e participar nas perdas do exercício, nos moldes previstos nos estatutos.

20. A participação nas perdas, nunca será apurada em função da participação no capital, mas antes em proporção das operações realizam das com a cooperativa, o que realça o pendor personalista das cooperalivas em relação ao capitalista.

21. Alendendo à especial ligação da cooperativa aos seus membros incidem também sobre eles o dever de lealdade, que se traduz na obrigação de não concorrência e na obrigação de sigilo.

22. O incumprimento dos deveres decorrentes das normas legais, dos estatutos e até dos regulamentos internos pode dar lugar à aplicação de sanções ao membro que as infringir.

23. A verificação de determinadas condutas, ou omissões imputadas aos membros da cooperativa poderá dar lugar ao exercício da acção disciplinar, que cabe, regra geral, ao órgão de administração da cooperativa.

24. No Código Cooperativo Português prevêem-se algumas sanções, ao passo que na Lei de Cooperativas da Galiza se remete nesta matéria para os estatulos.

25. No entanto, quando a sanção a aplicar for das mais gravosas, em especial, a da exclusão de membro da cooperativa, a competência é atribuída à assembleia geral, cabendo-lhe deliberar sobre a sua aplicação.

26. Exceptuado este caso, à assembleia geral é atribuída em matéria disciplinar competência para apreciar os recursos interpostos da aplicação das sanções.

27. A aplicação de sanções aos membros da cooperativa está sujeita a um processo com algumas formalidades, que acima de tudo procuram garantir a defesa do membro.

28. Processo esse que sofre determinadas exigências formais quando a sanção aplicar for a exclusão da cooperativa.

29. Em todas as situações está garantido ao membro o direito a ser ouvido, podendo defender-se por escrito e requerer a realização diligências probatórias. 
30. Em ambas as legislações se estabelecem prazos para o exercício da acção disciplinar.

31. Obrigatoriamente, ou voluntariamente, e eventualmonte com a sua morte, deixará o membro de pertencer à cooperativa, caso em que perderá a qualidade de cooperador ou de sócio.

\section{BIBLIOGRAFIA}

ABREU, Jorge Manuel Coutinho de. Da empresarialidade - as empresas no direito. Coimbra: Almedina, 1996. ISBN 972-40-0956-4.

- Curso de Direito Comercial, Das Sociedades. Vol II. Coimbra: Livraria Almedina, 2002. ISBN 972-40-1646-3.

ASCENSÃO, José de Oliveira. Direito Comercial, Sociedades Comerciais. Vol IV, Lisboa: 1993.

MORILLAS JARILLO, Maria José e FEL IÚ REY, Manuel Ignacio, Curso de Cooperativas. segunda edición, Madrid: Editorial Teenos, 2002. ISBN 84-309-3902-4.

RODRIGUES, José António. Código Cooperativo, anotado e comentado e legislação cooperativa. 3. ${ }^{\text {a }}$ ed.. Lisboa: Quid luris, 2001. ISBN 972-724-()86-0.

TATO PI AZA, Anxo e COSTAS COMESAÑA, Júlio. Legislación. Cooperativa en Galicia. Tórculo Edicións, 2000. ISBN 84-8408-224-5.

\section{LEGISLAÇÃO}

Código Cooperativo Português, Lei n. ${ }^{\circ} 56 / 91$ de 7 de Setembro, alterada pelo Decreto-Lei n. ${ }^{\circ} 343 / 98$ de 6 de Novembro, pelo DecretoLei $n .{ }^{\circ} 131 / 99$ de 21 de Abril, pelo Decreto-Lei $n^{\circ}{ }^{\circ} 108 / 2001$ de 6 de Abril e pelo Decreto-Lei n. ${ }^{\circ}$ 204/2004 de 19 de Agosto.

Ley 5/1998, de 18 de diciembre, de Cooperativas de Galicia, BOE num 72 de Jueves 25 marzo 1999, pp. 11568 a 11606 . Publicada en el "Diário Oficial de Galicia" número 251,30 de diciembre de 1998. 